\title{
From Temür to Selim: Trajectories of Turko-Mongol State Formation in Islamic West-Asia's Long Fifteenth Century
}

\author{
Jo Van Steenbergen
}

This chapter presents both a general overview and trans-dynastic interpretation of the power elites of fifteenth century Islamic West-Asia, their institutions and practices, and the many transformations that marked their trajectories across the rough political landscape of the time. ${ }^{1}$ As far as that overview is concerned, the chapter retraces the general contours of these many crisscrossing trajectories of trans-regional, regional and local empowerment that distinguished the landscape from Nile to Oxus and from Bosporus to Indus between the end of the fourteenth and the beginning of the sixteenth centuries $\mathrm{CE}$ (or the end of the eighth and the beginning of the tenth centuries $\mathrm{AH}$ ). In a rather traditional fashion, the chapter focuses in particular on describing specific trajectories of trans-regional empowerment. These appeared in the format of dynastic and non-dynastic hegemonic constellations of power elites that engaged in competing politics of conquest, integration, reproduction and exploitation, or of war-making and state-making, on a trans-regional or even West-Asian scale. The chapter will of course also have to consider other trajectories of empowerment as equally meaningful components of fifteenth-century Islamic West-Asia's political history, even when they did not necessarily involve or relate to any identifiable processes of state-making. The latter trajectories range from those on the more local level of non-complex social groups related to a town, village, urban neighborhood, tribal pasture or small-scale community to regional ones, operating within more complex composites of social groups,

1 This chapter has been finalized within the context of the project 'The Mamlukisation of the Mamluk Sultanate II: Historiography, Political Order and State Formation in FifteenthCentury Egypt and Syria' (UGent, 2017-21); this project has received funding from the European Research Council (ERC) under the European Union's Horizon 2020 research and innovation program (Consolidator Grant agreement No 681510). My sincere thanks go to Evrim Binbaş, Frederik Buylaert, Kenneth Goudie, Zacharie Mochtari de Pierrepont and Patrick Wing for reading and commenting upon earlier versions of this chapter. Needless to say, I take sole responsibility for the interpretations presented here as well as for any remaining inaccuracies. 
especially in particular geographic and ecological units of West-Asia's diverse landscape. For mostly practical reasons, the consideration of these local and regional trajectories will mainly be organized around their multivalent intersections with those dominant trans-regional trajectories of the Ottomans in and beyond Islamic West-Asia's Northwest, of various Timurid and Turkmen dynasts in its North and East, and of the sultans of Cairo in the Southwest. In these ways this chapter aims both to make fifteenth-century Islamic West-Asia's political history in general more accessible and intelligible to wider audiences and to contextualize this volume's specific case studies, all of which relate to the remarkable processes of expansion and centralization that marked those trans-regional trajectories.

This chapter also invites specialists of the histories of these different trajectories to rethink their understanding within the wider frameworks of West-Asian connectivity and state formation. To this end, it adopts an entangled and thematic approach to these histories. This means that this chapter crosses the boundaries that tend to continue to divide West-Asia's history into separate, dynastically-organized research traditions in particular amongst Ottomanists, Mamlukologists and Timurid-Turkmen specialists. The chapter aims to integrate those dynastic boundaries more explicitly into its explanations and interpretations, seeing these as markings of variations on deeply interconnected trans-dynastic phenomena and as common sources of meaningful distinction in particular historical and historiographical contexts. In order to do so, this chapter reconstructs those phenomena and contexts into meaningful descriptive and interpretive units. The choice of units is informed by current (especially minimalist and practice-oriented) theoretical understandings of premodern states, of how they become, and what they do (and not do), as detailed in the following chapter. ${ }^{2}$ The first part of the current chapter consists of introductory

2 For the sake of clarity, it is already relevant to refer here to Charles Tilly's historicizing definitions of what states are and what they do. These will be explained (and problematized) in more detail in the next chapter. However, it is a deliberate choice to allow these definitions to substantially inspire the focus and organization of this chapter. Tilly sees states as "coercionwielding organizations that are distinct from households and kinship groups and exercise clear priority in some respects over all other organizations within substantial territories" (Tilly, Coercion, Capital, and European States, p. 1). Elsewhere he outlines what he thinks these organizations did in the following minimalist terms: "Under the general heading of organized violence, the agents of states characteristically carry on four different activities: 1 . War making: Eliminating or neutralizing their own rivals outside the territories in which they have clear and continuous priority as wielders of force; 2 . State making: Eliminating or neutralizing their rivals inside those territories; 3 . Protection: Eliminating or neutralizing the enemies of their clients; 4. Extraction: Acquiring the means of carrying out the first three activitieswar making, state making, and protection". (Tilly, "War Making and State Making”, p. 181). See 
explanations that describe the main political players and playgrounds in Islamic West-Asia, while the second part takes an interpretive approach to discuss the rules and stakes of these games of power. This approach builds upon a general scholarly consensus concerning basic facts and figures, and as the next chapter engages in much detail with the current state of relevant Ottoman, Timurid-Turkmen and Syro-Egyptian political history research, literature references here are kept to a minimum, used only to support, illustrate or explain certain interpretations. This approach continues in the third part of the chapter, moving towards a more critical consideration of the historical dynamics that help to better understand the remarkable interplay of socio-political continuities and changes in Islamic West-Asia's political history. These continuities and changes appear as specific fifteenth-century convergences of phenomena that are all similarly related to processes of state formation and therefore invite to be considered from trans-regional and trans-dynastic perspectives. They include the contingency of centralizing longevity, the integration of distant power elites through multivalent processes of bureaucratic growth, the particularity of outsiders' coercive integration as a strategy of elite renewal, and simultaneously the reproduction of central elites in highly competitive ways. In the discussion of these different phenomena, occasional reference is also made to the different chapters in Parts 2 and 3, and to how their case studies make for highly illustrative examples. An epilogue finally considers the nature and formation of fifteenth-century socio-political boundaries and how these relate to specific formulations of an ideal, discursive framework of social order and political sovereignty.

\section{1 \\ Situating Agents and Agencies of State Formation in Fifteenth- Century West-Asia}

The late fourteenth century reign of the Central-Asian ruler Temür (r.1370-1405) was a kind of matrix moment for the histories of Islamic West-Asia's main fifteenth-century polities and political elites. Temür, also known as Tīmūr in Arabic and Persian, or as Tamerlane in European languages, certainly had a remarkable career. Remembered especially for his feats of conquest, plunder and fearsome havoc on a Eurasian scale, Temür also stands out for the unique level of personal empowerment, cultural efflorescence and successful state formation that he achieved in the Mongol, Turkish and Muslim contexts of

also Chapter Two in this volume, especially "Introduction: Defining the 'state' between Max Weber, 'Abd al-Rahman Ibn Khaldun and Charles Tilly". 
both the Chagatai nomadic polity of Central-Asia and the ancient urban centers and cultures of Transoxiana, Khurasan and Iran. Across Islamic West-Asia, Temür's successes stimulated the consolidation of hybrid leaderships, political identities and charismatic hegemonies that often combined Turkmen, Turkish, Kurdish, Arabo-Persian and Mongol facets. In fact, his personal politics of conquest enabled not just the rise to power of his family and entourage as a new trans-regional elite in Islamic West-Asia, but also led to the new or renewed empowerment of various local and regional elites, particularly those of a Turkmen nomadic background. In this way Temür's political action confirmed and boosted the so-called "eastward reflux" of Turko-Mongol leaderships, following the thirteenth-century wave of westward expansion from Mongol Inner Asia. ${ }^{3}$

This important moment in West-Asia's history indeed brought to power an entirely new, mostly peripatetic trans-regional power elite in Transoxiana, Khurasan and Iran (see map 2). This new elite was composed of two different groups. On the one hand there were Temür's many descendants who grew into a new dynasty of Turko-Mongol royal status known as the Timurids. On the other hand, there were the military leaders of Temür's armies, who stemmed from various Turko-Mongol Chagatai origins. Tried, tested and bred in the personal entourage of Temür, these princes and commanders continued to dominate these eastern regions' politics for many decades after Temür's death, and in varying constellations and associations that included also their own descendants. In Transoxiana and Khurasan this highly dynamic Timurid domination even lasted up to the turn of the fifteenth to sixteenth centuries (see map 4).

Beyond these core areas of Timurid leadership, Temür's conquest politics of undermining or annihilating the authorities of regional and trans-regional rivals created political opportunities for various local power elites, including tribal leaderships and messianic movements, especially in the regions stretching from Iraq and Azerbaijan to Anatolia (see map 1). Throughout most of the century, these regions, with their ideal winter and summer pastures, their

3 See Loiseau, "Le siècle turc", p. 36, who takes this notion of a reflux from Woods, The Aqquyun$l u$, p. 3, who, in turn, explains that he took it from the pioneering studies of Minorsky and Sümer: "Amplifying the earlier view of Minorsky, Sümer notes the eastward reflux from Anatolia of the Mongol Oirot, Jalayir, and Süldüz after 1335/736 in addition to the three Turkmen 'waves' composed of the Qaraquyunlu, the Aqquyunlu, and the Safavid Qizilbash that swept out of Anatolia over Iran in the fifteenth/ninth and sixteenth/tenth centuries". (see Anonymous. Tadhkirat al-mulük: a manual of Șafavid administration (ca. 1137/1725), V.F. Minorsky, ed. and trans. (E.J.W. Gibb memorial series vol. 16) [London: Luzac, 1943], appendices, p. 188; Faruk Sümer, Oguzlar (Türkmenler), tarihleri, boy teşkilâtı, destanları (Ankara: Üniversitesi Basımevi, 1967), pp. 143-153). 
fertile river basins, and their multiple commercial networks of towns and routes, remained a politically unstable and poly-centric area, characterized not only by intense mobility but also high fluidity. They may therefore be considered one of fifteenth-century Islamic West-Asia's main frontier zones; an area where "one could move from place to place, allegiance to allegiance, and identity to identity with an ease and acceptability hard to even imagine in more settled societies". ${ }^{4}$ In fact, connecting West-Asia's centers of somewhat more stable political, commercial and cultural activities (especially—but not exclusively - the urban centers of Bursa, Edirne and Constantinople in the Northwest; Aleppo, Damascus and Cairo in the Southwest; Tabriz in the North; and Herat and Samarkand in the East) those towns and routes of Iraq, Diyar Bakr, Azerbaijan, Armenia and Anatolia, and the diverse local elites that controlled them, remained a trans-regional bone of contention, and thus were a genuine frontier zone, marking the borderlands between remote but ambitious trans-regional leaderships, such as that of the Timurid Shah Rukh (r. 1409-47) in the East, of the Ottoman sultans Murad (r. 1421-51), Mehmed (r. 1451-81) and Bayezid (r. 1481-1512) in the Northwest, and of the Sultanate of Cairo and its many mamlük rulers, including the sultans Barsbay (r. 1422-38), Jaqmaq (r. 1438-53), Qaytbay (r. 1468-96) and Qansawh (r. 1501-16), in the Southwest.

First subdued by Temür's passage through Anatolia and Syria in the opening years of the fifteenth century and then all but annihilated by subsequent years of territorial fragmentation and internecine warfare, the Ottoman and SyroEgyptian polities only re-emerged as strong trans-regional power centers from about the mid-141os onwards (see map 2). In the process, as will be detailed below, newly composed politico-military elites rose to power in both Sultanates, and both had in common their origins of enslavement (mostly in the Balkans and in the Caucasus respectively), socialization in royal military and court service, and acculturation to particular Turkic-Muslim political identities. In many ways, these power elites thus became more alike than would be suggested by their organization around the century-old Ottoman dynasty in the Northwest and the even older Sultanate of Cairo in the Southwest. In the course of the fifteenth century a scramble for West-Asian control and influence regularly pitted these elites and their sultanic rulers against each other. Initially this conflict mostly happened indirectly, through local and regional

4 Kafadar, Between Two Worlds, pp. 140-141; here he is speaking of Western Anatolia, but the definition works equally well for this frontier zone in the fifteenth century. For an illustration of frontier conditions in this zone in the 1420 and 1430 s, see Adriaenssen and Van Steenbergen, "Mamluk Authorities and Anatolian Realities". 
intermediaries, but increasingly it was also direct, through diplomatic exchange and military confrontation. To some extent, the campaigns of the Ottoman sultan Selim (r. 1512-20) in Azerbaijan in 1514 and his conquests of Syria in 1516, and then of Egypt in 1517, also fit into this complex pattern of ongoing regional competition for sovereignty, influence and control in that enormous frontier zone of fifteenth-century trans-regional politics. At the very least, these campaigns and conquests of the early sixteenth century radically changed the stakes that had dominated the previous century, forcing many elites and activities in the frontier zone of Armenia, Diyar Bakr and eastern Anatolia to become more firmly integrated into an exclusively Ottoman framework of sovereignty, endeavoring to push political boundaries out- and eastwards, and allowing them to be reframed more simply along an ancient EastWest politico-military axis.

Before that re-orientation of the political landscape of West-Asia, however, this gigantic poly-centric zone-connecting in myriad ways Egypt, Northwest Anatolia, and Khurasan and Transoxiana-operated very much as a laboratory of fifteenth-century political (and cultural) experimentation. This involved various local and regional elites and their shifting loyalties as much as the more remote and continuously contested trans-regional leaderships of Timurids, Ottomans, Turkmen and 'Turks' (as the Syro-Egyptian Sultanate's politico-military elites were identified by their contemporaries). ${ }^{5}$ In the historical regions of Southern and Eastern Anatolia, Azerbaijan, Armenia, Diyar Bakr and Iraq in particular, various old and new movements, networks, communities and chieftainships benefitted, with varying degrees of success and sovereignty, from the renewed local political opportunities created by both

5 In remarkable contrast European and modern historiography generally all refer to members of this Syro-Egyptian power elite as Mamluks (as a result of the mamlük, or military slave status of the majority of them) rather than 'Turks'. However, this is an external label that poses many interpretive challenges for significant but as yet largely unacknowledged reasons (see Ayalon, "Bahrīi Mamlūks, Burjī Mamlūks"; Yosef, "Dawlat al-Atrāk or Dawlat al-Mamālīk?"; Van Steenbergen, "Nomen est Omen"; Van Steenbergen, "Mamlukisation between social theory and social practice"). In the first part of this volume we will therefore use this traditional Mamluk label when referring to the field of 'Mamluk' studies only, and not when referring to this Sultanate and its elites. When referring to the latter we draw on an interesting analogy (and synchronism) with standard references to the North-Indian Delhi Sultanate or Sultanate of Delhi (1206-1526) and its different ruling dynasties, including of mamlūk and Turkish origins. We will therefore mostly use the signifiers 'Cairo Sultanate' or 'Sultanate of Cairo' and 'Syro-Egyptian elite' in this volume's first two chapters (see e.g. Peter Jackson, The Delhi Sultanate. A political and military history [Cambridge: Cambridge University Press, 2003]; Iqtidar Husain Siddiqi, Composite Culture under the Sultanate of Delhi. Revised and Enlarged Edition [Delhi: Primus Books, 2016]). 
Temür's campaigns and subsequent contested trans-regional leaderships. Within this fluid, permeable and poly-centric zone many participated in the endless negotiations of local balances of socio-economic, political and cultural interests with violence, charismatic leadership, millenarianist ideas and diplomatic pragmatism. ${ }^{6}$ Throughout the century, however, some leaderships emerged as more successful, more powerful and more regionally reputed than others in a wide range of different local contexts.

In this way, the Karamanid dynasty was first subdued by the Ottomans but then restored to their fourteenth-century regional primacy by Temür, and eventually claimed priority from the ancient Anatolian capital of Konya throughout much of the South-central Anatolian mountain lands and plains. Especially during the long and expansionist rule of Ibrahim Beg Karamanoglu (r. ca. 1423-64), the Karamanid leadership vied variously and in alternating ways with other Anatolian chiefs as well as with the Ottoman and 'Turkish' sultans for local and regional sovereignty. The Karamanids had two main competitors among these Anatolian leaderships: the Ramadanids who sought to impose some form of regional authority and control over the Cilician coastal plains from the towns of Tarsus and Adana, and the Dulkadirid lineage, similarly claiming priority on the Anti-Taurus plateau from their seats of power in the towns of Elbistan and Maraş (Kahramanmaraş) (see maps 2 and 3). From the late 146os onwards, external pressures on these so-called 'Turkmen' dynasties in South-central Anatolia increased at a varying but unrelenting pace to the extent that they were all eventually subdued by, or fully integrated into the trans-regional claims to power and sovereignty that were emanating ever more intensely from Ottoman Constantinople in particular, as well as from Cairo (see map 4).

In the regions of Diyar Bakr, Armenia, Azerbaijan and Iraq competition for local and regional priority and assets was dominated by two other Turkmen tribal groupings (see map 2). These groups seem to have maintained a higher level of transhumant activity than their Dulkadirid, Ramadanid and Karamanid peers. The chiefs of the Qara Qoyunlu (the Clan of the Black Sheep) were among the few fourteenth-century regional leaderships that managed to survive Temür's onslaught and they eventually even regained priority status in and beyond their former east-Anatolian territories. This was above all thanks to their charismatic Qara Qoyunlu chief Qara Yusuf (d. 1420), whose military

6 See e.g. Binbaş, “Did the Hurufis Mint Coins?", p. 139, which refers briefly to various "intellectual movements which acquired a political character and minted coins in the late medieval period", as well as to "other cases in which the boundaries between tribal-cum-local elites and religious-intellectual networks are blurred or cannot be drawn accurately". 
successes from 1406 onwards established his sovereignty over all of these regions, effectively forming a block within this enormous zone between the Caucasus and the Persian Gulf which hindered the territorial ambitions and interests of the Timurid Shah Rukh in Herat in particular. Qara Yusuf's son and successor Iskandar (d. 1438) was confronted with the consequences of this growing tension, in the form of substantial pressures from Shah Rukh and his armies as well as from various local groups acting as allies to the Timurids or others. These pressures eventually all proved ineffective, and Iskandar's son Jahan Shah (r. 1439-67) managed to consolidate his predecessors' achievements, even stepping into the Timurid void after Shah Rukh's death and establishing his own sovereignty over many formerly Timurid lands in Iran. Jahan Shah achieved this from the Qara Qoyunlu center in Tabriz, eventually evolving into an awe-inspiring trans-regional ruler in his own right over most of central West-Asia (see map 3).

In 1467, when Jahan Shah was captured in battle and executed, the story of Qara Qoyunlu trans-regional leadership in Eastern Anatolia, Armenia, Azerbaijan, Iraq and Iran proved to be short-lived. However, more consolidated Turkmen rule in these regions continued along very similar lines, when Uzun Hasan (r. 1457-78), leader of the Aq Qoyunlu (the Clan of the White Sheep), seized the opportunity to step into Jahan Shah's footsteps. This led to the accommodation, absorption or integration of Qara Qoyunlu (and formerly Timurid) relationships, balances, and achievements into an adapted transregional order, now dominated by the Qara Qoyunlu's longstanding Anatolian rivals of the Aq Qoyunlu. It also meant that the Aq Qoyunlu tribal group and its leaders finally extended their influence beyond the mere control of the trade routes and the transhumant network of Diyar Bakr and Southern Armenia (see maps 2 and 3). This zone until then had defined their area of operation, competition and relationships since the days of the alliance between Temür and one of the Aq Qoyunlu's most charismatic early chiefs, Uzun Hasan's grandfather 'Uthman Beg Qara Yuluk (d. 1435). Uzun Hasan and his immediate successors now took Tabriz in Azerbaijan as their seat of power and they maintained for more than three decades at least some level of sovereignty over the highly diverse chain of lands, people and resource flows that connected the Caucasian mountain lands, the Iraqi lowlands and the Iranian plateau (see map 4). In that enormous frontier zone of fifteenth-century trans-regional politics these territories thus increasingly became a more or less coherent political space that was organized around Turkmen leadership in Tabriz. In the Southwest, the expansion of this new political coherence was curbed by Syria's ancient dominance from Cairo. In the Northwest its reach was limited by an equally increasingly coherent Ottoman sovereignty and Anatolian dominance, sealed 
by the Ottoman victory over Uzun Hasan at the Battle of Bashkent in eastern Anatolia in 1473. In the East, the reach of Turkmen transregional authority continued to be checked by Timurid princes claiming leadership from the main urban centers of Khurasan and Transoxiana.

\section{Situating Practices and Institutions of State Formation in Fifteenth Century West-Asia}

In some ways these competing leaderships of fifteenth-century Islamic WestAsia, from Ottoman, Syro-Egyptian and Timurid sultans to various Turkmen leaders and rulers, all have similar profiles, marked by the marginality of their social origins, the martial nature of their socio-political identities and the 'Turkishness' of their linguistic and cultural idiom. Given the common setting of their political action amidst Islamic West-Asia's settled Arabo-Persian environments, the historical profiles of these sultans, leaders and rulers are all also marked by the same experimental creativity and hybrid mix of memories, practices and institutions that they and their entourages used to explain and reproduce the messy and often violent political realities that emerged from these marginal, martial and Turkish contexts. Across Islamic West-Asia, these diverse fifteenth-century realities of leadership and their explanations all remained deeply rooted in longstanding interconnected imaginations and traditions of trans-regional political action. This type of political connectivity is often labeled as the Turko-Mongol factor of fifteenth-century Islamic West-Asia. This is a shorthand for capturing the combined features of nomadic (or semi-nomadic) roots and Perso-Islamic, Turko-Saljuq and Mongol-Chinggisid precedent that determined in multivalent structuring ways these realities and explanations of political action across fifteenth-century Islamic West-Asia.

The second part of this chapter will provide an overview of those TurkoMongol features that are central to understanding fifteenth-century Islamic West-Asia's history and the politics of its leaderships. These involve particular practices and institutions of socio-political reproduction and transformation, of socio-economic accumulation and redistribution, and of political organization and state formation. These main practices and institutions of TurkoMongol politics are discussed here only in a general way. As announced above, the purpose here is to frame these features from trans-dynastic perspectives and informed by state formation studies. As such an approach is not very common within the field of fifteenth-century Islamic West-Asian history, it has to be stressed that the occasionally more unorthodox interpretations that are 
also presented here are above all intended to stimulate further discussion and exploration.

\subsection{Turko-Mongol Socio-political Praxis}

The presence and impact of the Turko-Mongol factor as outlined above have been generally regarded as being most visible through the widespread ancient appanage and tanistry practices that continued to regulate the distribution and reproduction of power, status and resources within elite lineages and political communities. These practices operated in diverse and multivalent ways between Cairo, Constantinople, Tabriz and Herat, and they continued to reinvigorate centrifugal tendencies and to obfuscate or even obstruct the pathways towards political stabilization and centralization, albeit with varying levels of success. Appanage and its cognate tanistry refer to the fact that the TurkoMongol mindset considered entitlement to privileges and social distinction, as well as succession to status, wealth, power and authority, as collective elitist arrangements. At the same time, these arrangements were nowhere organized in any straightforward hierarchies of individual rights, priorities and obligations. Rather, they always had to be acquired in highly competitive social circumstances, and agnatic kinship and seniority were only one asset among many here, alongside highly individualized qualities such as ambition, charisma, political acumen, coercive prowess and even longevity. Political participation in this context of regular dynastic fragmentation and violent succession to leadership was not just a matter of birth or choice, but also of social survival and necessity, and power elites were left with no choice but to partake actively and continuously in political action. As a result, this politicization of all social relationships continued to favor the individual expertise and personal clout of successful military entrepreneurs among the members of those elites. "[Tanistry] politicized society, and it personalized monarchy", as one of the pioneers of the study of Inner Asian and Turko-Mongol politics, Joseph Fletcher, put it. ${ }^{7}$

7 Fletcher, "Turco-Mongolian Monarchic Tradition in the Ottoman Empire", p. 240. See also Woods, The Aqquyunlu, pp. 19-23 (following Dickson, "Uzbek Dynastic Theory in the Sixteenth Century") for a more nuanced (if limiting) consideration of the tensions between socalled corporatism and dynasticism that together constitute tanistry as it is conceptualized here. Whereas in the Ottoman context, as Fletcher argues, this practice gave rise to the wellknown (and eventually codified) royal succession tradition of fratricide, its dividing presence in and impact on Timurid and Turkmen dispensations is also well known. (See also Binbaş, "Condominial Sovereignty and Condominial Messianism" for an interesting corrective about shared notions of rule in certain Timurid contexts). This phenomenon is perhaps most tellingly illustrated by the ways in which the Qara Qoyunlu ruler Jahan Shah stepped into the footsteps of the Timurid Shah Rukh or how the Aq Qoyunlu ruler Uzun Hasan stepped into those of Jahan Shah. For examples and discussions from the Cairo Sultanate in the Southwest, 
In this context of Turko-Mongol political praxis, success was highly personal, and leaders such as Temür, Murad, Jaqmaq, Uzun Hasan and their peers and descendants had to constantly fight for their survival. Political order and stability were a widely shared responsibility as well as a highly volatile symbolic construction, which faced continuous pressures, both from within and from without. In fact, as will be detailed below, the Ottoman Sultanate in the Northwest, its 'Turkish' counterpart in the Syro-Egyptian Southwest, the Timurids in Khurasan and Transoxiana and somewhat belatedly also the Turkmen in Azerbaijan and Iran managed to check the returning centrifugal consequences of these practices and pressures, even though in most cases only in contingent ways and to a certain extent. The process of state formation in these cases featured the gradual appearance of a coherent central political apparatus and of the concomitant idea that there was one autonomous 'Turkish', Ottoman, Timurid or eventually even Turkmen hegemonic political order. This process favored, in diverse ways, centripetal strategies that limited any effects of the elite fragmentations that were plaguing tanistric moments of succession in Cairo, in Edirne and Constantinople, in Tabriz, and in Herat and Samarkand. This never happened in any similarly stabilizing ways for other leaderships with trans-regional ambitions in fifteenth-century West-Asia, and the evaporation of Timurid authorities in Anatolia, Armenia, Azerbaijan, Iraq and WestIran and the successive territorial expansions of the Qara and Aq Qoyunlu between the 145 os and 1470 os had as much to do with these internal reproductive weaknesses as with the military successes of charismatic leaders like Jahan Shah and Uzun Hasan.

Most important for a proper understanding of the impact of Turko-Mongol socio-political praxis, perhaps, is the fact that, even under the latter Timurid and Turkmen umbrellas of unstable trans-regional leaderships, rapid political transformation had no more effect on the political practices and identities of most local and regional power elites in Eastern Anatolia, Armenia, Azerbaijan, Iraq and most of Iran than it did on their counterparts in the more stable political contexts of Ottoman Anatolia, 'Turkish' Syro-Egypt, or Timurid Khurasan and Transoxiana. Loyalties and allegiances shifted and sovereignties and regional priorities were constantly renegotiated, while political spaces and fields of power were incessantly redefined as a consequence of tanistric competition. In all of these regions, however, local and regional groups of political actors and their stakes and assets were far more enduring, changing primarily as a consequence of the many realities of social, cultural and physical mobility.

see Adriaenssen and Van Steenbergen, "Mamluk Authorities and Anatolian Realities"; Van Steenbergen, "Caught between Heredity and Merit". 
This relative social stability moreover not only concerned those who propagated rural or urban violence in ever changing political constellations, but it also characterized many other elite groups and individuals who wielded some form of leverage and political clout. All of this meant that across Islamic WestAsia, Turko-Mongol leaderships never fully achieved any monopoly of power as their political relationships tended to be crisscrossed, checked or even undermined not just by appanage and tanistry practices, but also by the assets, strategies, and tools of those who had other skills to tap into local and regional flows of cultural, political and economic resources. Beatrice Manz, in her study of the reign of the Timurid ruler Shah Rukh, described as follows the effect of this atomistic and highly volatile situation on the political landscape within which the Timurids operated:

The towns from which the Timurids ruled their dominions were like an archipelago within a sea of semi-independent regions, over which control was a matter of luck, alliance and an occasional punitive expedition. ${ }^{8}$

As illustrated by the different case studies of local and regional elites in Part 3 of this volume, this powerful archipelago metaphor is not just a very good approximation of the situation in West-Asia's Timurid East. On the ground, in and out of the limelight of trans-regional political power, all kinds of constellations of scholars, merchants, bureaucrats and local rural and urban leaders participated actively and often equally successfully in the translation and accommodation to local and regional realities of trans-regional claims to power and primacy. As will be detailed below, the social, cultural and financial entrepreneurship of these groups alongside their knowhow and access to all kinds of resources made them equally important, powerful and impactful both for the highly personalized and tanistric successes of all kinds of Turko-Mongol leaderships in West-Asia's more peripheral zones as well as for (or against) the more coherent processes of central state formation in the Ottoman Northwest, the 'Turkish' Southwest, the Turkmen North and the Timurid East of Islamic West-Asia. As it played out in fifteenth-century Islamic West-Asia, TurkoMongol socio-political praxis was therefore not just highly personalized, tanistric and violent. It also displayed a strong tendency towards fluidity and poly-centrism. All these Turko-Mongol qualifications therefore invite one to consider West-Asian power as a relational and circulating historical phenomenon that connected and disconnected local, regional and trans-regional social realities in myriad centrifugal and centripetal ways. The growing visibility

8 Manz, Power, Politics and Religion, p. 2. 
of the latter integrative tendencies in some parts of West-Asia should never obfuscate the continued workings of the former decentralizing and poly-centric forces in the peripheries as well as in the centers of the Ottoman, SyroEgyptian, Turkmen and Timurid trajectories of state formation.

\subsection{Turko-Mongol Political Economies}

These diverse local, regional and trans-regional elites were actually connected through access to Islamic West-Asia's many resources in more defining and structuring ways than they were through Turko-Mongol socio-political praxis. It is therefore also appropriate to give some consideration here to this, and to the diverse but related sets of tributary, fiscal and proprietor relationships and of redistributive arrangements that distinguished fifteenth-century Islamic West-Asia's political economies. These have to be understood against the background of a brief contemplation of the region's wider symbiotic nomadic, agricultural and commercial economies.

The recurrent tendency in Turko-Mongol politics towards "internecine warfare" did "minimal damage to a nomadic economy", as explained Joseph Fletcher. "[T]o an agricultural economy, on the other hand", Fletcher continued, "it was destructive, sometimes disastrous". ${ }^{9}$ For many centuries, West-Asia's diverse, rich and longstanding agricultural economies had been forced to accommodate the many changes wrought, in more and less destructive ways, by the influx of Inner-Asian nomads and their tanistric politics. In the fifteenth century, that accommodation continued, due both to the pressures of the Turko-Mongol reflux from West to East and the impact of more particular socio-economic phenomena, not least the mid-fourteenth-century Black Death pandemic and similar, more restricted, epidemic cycles of pestilence, plague and depopulation. Throughout Islamic West-Asia, a transhumant nomadic economy, controlled by Arab, Kurdish, Turkmen and many other tribal leaderships, had thus come to occupy a much more prominent space, and these groups often functionally shared the diverse rural landscapes of the region with agricultural ventures of a reduced and mostly relatively modest local scale. This created a particular trans-regional economic context that, though fundamentally different from any earlier trans-regional situation, proved resilient enough to the political realities of endless warfare to maintain a reasonable level of sufficiency.

An important factor here also was undoubtedly the fact that these symbiotic nomadic and agricultural economies were supported by the fifteenth-century mercantile networks that increasingly strengthened connections amongst

9 Fletcher, "Turco-Mongolian Monarchic Tradition in the Ottoman Empire", p. 242. 
and beyond West-Asia's many long-standing and densely populated urban centers and towns. This booming business of the circulation of local, regional and trans-regional merchants and commodities (including luxury goods such as spices and also slaves and furs) had also very successfully adapted to accommodate the recurrent political insecurities of the time, operating along rhythms of exchange and along flows of resources that managed to produce in many ways their own commercial realities. ${ }^{10}$ On a local level, these realities were undoubtedly also volatile, affected by ecological and demographic uncertainties and intersected by all kinds of competing interests that could be equally political and economic. Across the board, however, the era's political and economic volatilities did not necessarily mirror each other thanks to the resilience of local economic communities as well as their capacity to adapt. Many of these communities also empowered themselves by acting as links in the intensifying chains of West-Asian routes and towns that connected the Mediterranean, Inner Asian and Indian Ocean trade zones. Islamic West-Asia's fifteenth-century cultural efflorescence and its reputation as an age of cultural innovation and creativity, and of trans-regional networks of defining scholarship and knowledge practices, are very much testimony to the ways in which these changing socio-economic realities had somehow managed to accommodate the potentially destructive effects of Turko-Mongol political praxis.

Turko-Mongol political praxis in this post-Temür age, however, had also been shaped in many ways by those same socio-economic changes. The aforementioned appanage and tanistry practices of dynastic fragmentation and violent succession to leadership were not static normative devices that structured political action in unchanging or uniform destructive ways. They rather represented deep-rooted traditions that were constantly being re-invented and reimagined according to the necessities of time and space, thus offering many potential solutions to all kinds of challenges. This was also true of the challenges posed by the new political and socio-economic realities of the fifteenth century, and of the great variety of more or less successful solutions pursued across Islamic West-Asia by the new, or renewed, elites of the post-Temür era. This pragmatic interplay between leadership challenges and solutions played out most directly on the local level, when political and socio-economic realities intertwined and Turko-Mongol elites everywhere tried again to tap into

$10 \quad$ Apellániz Ruiz de Galarreta, Pouvoir et finance en Méditerranée pré-moderne; Inalcik, "Bursa and the Commerce of the Levant"; Inalcik, "Harīr. ii-The Ottoman Empire"; for wider commercial (and related political) connections east- and westward, see also Vallet, L'Arabie marchande; Meloy, Imperial Power and Maritime Trade; Coulon, Barcelone et le grand commerce d'Orient. 
the region's changing flows of resources and accelerating rhythms of exchange. The intense and highly interconnected cultural and intellectual life of fifteenthcentury Islamic West-Asia was very much an outcome of these pragmatic politics of local revenue extraction, thriving as it had before on the patronage of these elites, on the political needs of their competing leaderships, and on the many opportunities for others beyond the direct control of these particular elites. Cultural and intellectual innovation were stimulated by regional competition, by the ubiquitous scramble for social distinction and political legitimation, and by the fertile hybridization of Arabo- and Perso-Islamic, Turkic and Turko-Mongol lore, and these developments found a welcome partner in the West-Asian empowerment of the relatively small groups of highly mobile West-Asian power elites of the post-Temür era. Rather than being undermined by the era's continuous outbursts of rivalry and violence, the cultural efflorescence of the fifteenth century in many ways was sustained by the constant opportunities generated by these endless renegotiations of local, regional and trans-regional balances of interest. ${ }^{11}$

Across fifteenth century West-Asia, Turko-Mongol elites attempted in many different ways to tap into the region's flows of resources and rhythms of exchange. Even though fiscal institutional precedents created a semblance of uniformity, these attempts were determined by local circumstances as much as by trans-local ambitions or centralizing initiatives. The most defining factor in all this, so it appears, was actually the changing contingency of a political center's distance from, and level of control over the economic assets in a locality. Territories and periods marred by political competition, warfare and campaigns of conquest and redress were hit most forcefully by the potentially destructive economic effects of Turko-Mongol politics. In such contexts, harvests, livestock, commodities or other resources were invariably looted, and then distributed as booty among campaigners and their followers along ad hoc hierarchies of military investment and political interest. After Temür's endless campaigning, and throughout the fifteenth century, West-Asia's regions that continued to be most regularly plagued by these coercive politics of resource extraction were the politically unstable poly-centric zone of Iraq, Diyar Bakr, Azerbaijan, Armenia and Eastern Anatolia and their winter and summer pastures, fertile river basins and multiple commercial networks of towns and routes.

11 The Russian historian Vasilij Vladimirovič Bartol'd (1869-1930) already made this point regarding Timurid history; in due course it was framed with the label of a Timurid "renaissance", see Barthold, Ulugh-beg; Binbaş, Intellectual Networks in Timurid Iran, pp. 4-5. 
In many cases, however, mitigating arrangements between local and campaigning leaderships followed, or forestalled, such economically and politically disruptive moments. Often, precious gifts were exchanged and tributes in cash and kind were pledged to confirm such arrangements, generating alternative, more controlled mechanisms to provide a return on the investments required for military campaigning. Depending on the circumstances, and also on the extent to which promises could be enforced, such ad hoc settlements between local and central elites could transform into more structural arrangements, including varieties of what essentially were tax farming engagements. Indeed, throughout the fifteenth century, these fluid arrangements arguably shaped the majority of economic relationships between local and central elites across Islamic West-Asia, appearing from Egypt over Western Anatolia to Transoxiana as the means best suited to balance the continuities of local actors and practices against the volatilities of Turko-Mongol politics and socio-economic changes. Such arrangements required minimal investments from central elites and helped maintain some level of authority over more peripheral social or territorial spaces. At the same time, these practices integrated Arab, Turkmen, Kurdish or other urban, rural and tribal elites into the authority structures of a political center by giving them a stake in the maintenance of political and economic order. As suggested above, the nature and extent of those stakes, alongside the level of integration of local and regional elites, and even the identity of that political center remained the object of fierce competition, negotiation and transformation throughout the century and across the continent.

More direct and unilateral fiscal systems of resource flow tended to complement, marginalize or even displace tax farming and tributary arrangements in areas that were more stable politically such as Ottoman Anatolia, 'Turkish' Syro-Egypt or Timurid Khurasan and Transoxiana, as well as in the proximity and catchment area of powerful leaders, such as Jahan Shah and Uzun Hasan. In each of these West-Asian power centers, broadly similar invasive rural and urban tax regimes were in operation, inspired by longstanding local and regional fiscal traditions, and leading to greater integration of taxpayers, beneficiaries and financial administrators into centralizing economic and political orders. In all regions these more direct tax regimes derived from a combination of ancient Islamic taxes, most importantly the land tax —or kharaj —and the poll tax —or jizya - together with a range of customs duties and related, mostly urban, taxes and forced payments that were not similarly sanctified by Muslim scripture. For many centuries, especially the kharaj's tithe payments in cash and kind had provided a steady flow of income for the region's elites, and this did not radically alter in the fifteenth century. At the same time, however, the period's socio-economic changes certainly also affected the flow of those traditional 
resources, increasing the importance of other types of income, not least through these elites' fiscal and other forms of participation in West-Asia's, and Eurasia's, commercial economies. ${ }^{12}$

The redistribution of these fiscal and related resources among political elites in West-Asia was everywhere similarly organized as a regionally interconnected and dynamic practice of land tenure and remuneration rooted in a mixture of precedents. Most of the economic assets and activities in Islamic West-Asia that were somehow subject to more direct tax regimes were connected to lands and rights that legally (at least in theory) belonged to the ruler, in his capacity as the personification of the sovereign political order, or the state. This proprietorship was then parceled out in fiscal concessions and fiscal exemptions to his household, to his courtiers and military leaders, and to other relevant beneficiaries in return for their loyalties and services. In the Anatolian context the main type of grant in this practice of controlled, but devolved, royal remuneration and fiscal administration was known in Ottoman Turkish as a timar, and its holders, the timariot, were all cavalrymen (sipahi) with varying ranks, status and responsibilities. In 'Turkish' Syro-Egypt the Arabic noun iqta' was used to refer to a concession in the arrangements that organized and regulated the distribution of tax income to the Sultanate's various military commanders (amirs) and their bands of horsemen. In Timurid and Turkmen lands similar arrangements prevailed among the entourages of rulers, but there these fiscal, administrative and proprietorship grants were referred to as soyurghal, or also as tiyul or ulka. The various forms, names and arrangements which this prebendal practice took in fifteenth-century Islamic West-Asian courts were all rooted in shared local customs and traditions that often originated in the tenth-century history of the region. These forms, names and arrangements also overlapped everywhere in more or less explicit ways with the Turko-Mongol appanage practice of shared but segmented authority. Invariably, they confirmed military leaders of Turko-Mongol background in their role as receivers and beneficiaries in West-Asia's fiscal resource flows, as active partners and stakeholders in the region's economies, and as managers of their own socio-political, military and economic resources or estates, even during moments of accelerating central state formation. All over Islamic West-Asia this prebendal practice finally appeared as the normative way of organizing the political economy around successful trans-regional leaders and power

12 This point is especially made in Apellániz Ruiz de Galarreta, Pouvoir et finance en Méditerranée pré-moderne; for a strong argument supporting the idea of very active early Ottoman participation in the Mediterranean commercial economy, see Fleet, European and Islamic Trade in the Early Ottoman Empire. 
elites. Bound to be expanded and pushed to the contested social and territorial frontiers of these leaders' effective reach, however, this practice never entirely gave way to feudal hierarchies of benefit and service, but rather continuously intersected and competed with other arrangements such as centralizing fiscal regulations and local tax farming and tributary solutions, alongside alternative land tenure provisions, especially those for religious endowments (waqf).$^{13}$

In order to understand fifteenth-century Turko-Mongol political economies, it is also extremely relevant to consider in more detail the intersections between this multifarious prebendal practice, the latter construction of Muslim religious endowments and centralizing regulations which appeared in some of the politically more stabilized parts of West-Asia. The land tenure system of fifteenth-century Egypt in particular has been demonstrated to have undergone a remarkable transformation, generally identified as waqfization. This notion of waqf-ization stands for the legal process by which the status of taxable land was changed to that of waqf-land, by incorporating the land and the income that it generates into the semi-closed, religiously sanctified and tax-exempted socio-economic circuit of a religious endowment (waqf). Institutions for religious practice and education, their salaried staff and students and related forms of expenditure were very often part of this specific socioeconomic circuit. At the same time, in fifteenth-century Syro-Egypt, such circuit similarly often included amongst its main beneficiaries specific household and family members and the descendants of the private person who created the waqf and donated its main assets. For the latter reason in particular, the process of waqf-ization has also been likened to a process of de-centralization and privatization. Many, if not most, of the Sultanate's courtiers and political leaders, very often also including sultans themselves, pursued all kinds of legal and financial strategies to subvert the centralized system of land tenure and fiscal redistribution. They alienated state lands traditionally parceled out as iqta ${ }^{c}$ and acquired full control over their assets by assigning them to their religious endowments, and thus to the long-term benefit of particular religious institutions and, most importantly, of their family and household. As such, waqf-ization was an effective strategy for enabling the Syro-Egyptian Sultanate's elite families in particular to anticipate, contain and very often also overcome, at least in socio-economic terms, the volatilities of Turko-Mongol politics and the many political changes that affected the Sultanate in the fifteenth century. ${ }^{14}$

13 See Inalcik, "Autonomous Enclaves in Islamic States".

14 Amīn, Al-Awqā fwa-l-Hayā al-Ijtimā'cya; Petry, "Fractionalized Estates in a Centralized Regime"; Abu Ghazi, Tatawwur al-Hiyāza; Sabra, "The Rise of a New Class?". 
At the same time, however, recent research has begun to make clear that this is not just a question of decentralization or of socio-economic privatization and survival. It is also a story of a substantial political transformation in the fifteenth-century Sultanate. This was due to the fact that, over time, control over some of the largest and most profitable waqf-estates in the Syro-Egyptian realm was actually transferred back to the central state, in particular to an increasingly clearly defined small number of the highest court offices. Positions such as those of the 'chief commander of the armies' (atabak al-'asakir), 'senior head guard' (ra's nawba kabir), and 'grand chamberlain' (hajib hujjab) came to be directly associated with the financial management of major waqfs. In ways that warrant further research, these major waqfs had often been endowed by previous sultans and they were linked to the upkeep of Cairo's main religious infrastructures, such as the Mansuri hospital, the Ashrafi religious complexes inside and outside the city walls, or the Mu'ayyadi congregational mosque next to the Southern gate. This meant that any military leaders who occupied these powerful offices at Cairo's court also automatically acquired control over these important estates and their resources. These leaders were then given the opportunity to transfer to their own households the substantial surplus generated by these waqf-lands in Egypt and Syria. They thereby moved from the administration of one set of waqf-estates to another as they made their careers at court and accumulated ever more resources. In the meantime, most of these leaders also used the riches they assembled in this way to set up their own religious endowments, continuing the afore-mentioned waqfization process and working to the socio-economic benefit of their own households and families. ${ }^{15}$ In many ways, therefore, the accelerating transformation of Egypt's land tenure system through waqf-ization and the paradoxical reintegration of waqf-estates in the state apparatus were related factors. They both contributed to, but were also partly generated by, the formation in Cairo of a small but particular set of state actors. As will be discussed in more detail below, these figures all rose from very humble origins, distinguished themselves through many years of military and court service, and eventually managed to accumulate substantial political and economic resources in the process. Different sets of these particular state actors, and their huge personalized resources, continued to influence successions and the political stability within the Sultanate throughout the fifteenth century. A handful of these men, including figures such as Jaqmaq (r. 1438-53), Inal (r. 1453-61), Khushqadam (r. 1461-7), Qaytbay (r. 1468-96) and Qansawh (r. 1501-16), even managed to

15 Igarashi, Land Tenure and Mamluk Waqfs, esp. pp. 29-32, 42-45; Van Steenbergen \& Termonia, "State Formation, Military Entrepreneurship, and Waqfisation". 
rise to the highest court office of sultan after long careers of service and of resource accumulation.

Elsewhere in Islamic West-Asia, the waqf institution also continued to play an important role in structuring socio-economic and political relationships. In the Ottoman and Timurid territories, as well as in the more fluid zone of Eastern Anatolia, Armenia, Diyar Bakr, Iraq, Azerbaijan and Iran, this infrastructure similarly enabled the structural patronage, cultural promotion and political integration of wide varieties of particular religio-cultural communities and their leaders, followers and practices. In these parts of Islamic West-Asia, the waqf institution also provided for a legal and socio-economic mechanism to protect elite families, households and other social groups against the vicissitudes of Turko-Mongol politics. However, only some of these endowments were integrated or linked with the political apparatus of these regions' rulers. As semi-closed local or regional circuits of agricultural, manufactural and commercial estates and assets, of expenditure for specific religious and communal purposes, of sovereign provisions prescribed by Islamic scripture and the law, as well as of rural and urban expertise, the majority of waqf endowments in Islamic West-Asia actually operated as an alternative, unusually stable, set of socio-economic arrangements for various elite groups to participate in the endless negotiations of local and regional relationships and balances of power. The semi-closed, sovereign and communal character of the waqf institution actually made it into a very powerful centrifugal instrument in the hands of power elites. It facilitated the intersection of centripetal ambitions and relationships emanating from Bursa, Edirne and Istanbul, from Tabriz, Herat, and Samarkand, and even from Cairo and Damascus with other equally powerful, institutionalized relationships, which had substantial socioeconomic, cultural as well as political impact on a local or regional level. As explained above, in fifteenth-century Cairo this centrifugal dynamic was somehow complemented by a more constructive participation of waqf endowments in the state formation process. In the East, Timurid rulers and their entourages started pursuing a parallel re-integration and more centripetal operationalization of the waqf (vaqf in Persian) institution within the politics of the central court. ${ }^{16}$ In Anatolia, however, the Ottoman state pursued a different policy, changing the legal status of rural properties and endowments (vakif in Ottoman Turkish), or even seizing them. This happened to increasing numbers

16 Subtelny, Timurids in Transition, esp. Chapter Five: "Piety and Pragmatism: the Role of the Islamic Endowment" (pp. 148-191); McChesney, Waqf in Central Asia, esp. Chapters Two ('The Origins of the 'Alid Shrine at Balkh') and Three ('Waqf in its Political Setting') (pp. 21-70). 
of rural properties and endowments belonging to groups and families in various parts of Western, Central and eventually even Eastern Anatolia. This forced expansion of the Anatolian land tenure system under direct Ottoman control was actually part and parcel of the process of centralization that followed sultan Mehmed's (r. 1451-81) conquest of Constantinople in 1453. Many local Anatolian elites' privately-owned and waqf lands were transferred to become Ottoman state lands (miri). They thus ended up as property of the Ottoman sultan in his capacity as the personification of the Ottoman political order and were parceled out as timars to the sultan's cavalry elites, the sipahi, or these lands were at least tied to a requirement of some form of military service from its original proprietors. In the process of the formation of the Ottoman state in the fifteenth century, therefore, it were the radical annihilation of the waqf institution's atomistic and even centrifugal dynamic as well as the maximization of the timar system as a function of the expansion of the dynasty's military apparatus that were the main targets of the central Ottoman court's socioeconomic policy. ${ }^{17}$

\subsection{Turko-Mongol Political Apparatuses}

These diverse redistributive arrangements in the political economies of Islamic West-Asia were all also interrelated as far as the administrative and authority structures that appeared to organize them are concerned. At this point it is therefore necessary also to briefly outline the organizational appearances of Turko-Mongol political power in fifteenth-century Islamic West-Asia and to consider their differing levels of complexity and penetration in and beyond the main centers of Ottoman, Syro-Egyptian, Turkmen and Timurid power, and also to explore how they transformed throughout the century.

As suggested above, these organizational arrangements all operated along devolved and even atomistic modes of power and control that remind us of the appanage practices of Turko-Mongol politics. These arrangements and their varying degrees of political integration often also coalesced with those practices and provided them with a more structured, institutionalized, appearance. Most of the princes, courtiers, military commanders, cavalrymen and other urban, rural and tribal leaders and elite communities of fifteenth century Islamic West-Asia were all very much left to their own devices with regards to organizing access management for the resources they controlled or which had been assigned to them. Even holders of a timar, an iqta ${ }^{c}$ and a soyurghal had to attend to their own economic and military needs and responsibilities, and they

17 İnalcık, An Economic and Social History of the Ottoman Empire, pp. 126-131; Inalcik, "Autonomous Enclaves in Islamic States", pp. 118, 124. 
mostly did so in organizational formats that appeared like down-scaled versions of trans-regional rulers' courts and administrations.

This segmentation of how fiscal relationships were organized in fifteenthcentury Islamic West-Asia, even in the vicinities of strong rulers and expanding states, is another function of the personalized nature of Turko-Mongol politics. The remaining instability and volatility of political realities across the region regularly cut across processes of more intense trans-local political integration and subordination of elites, even in the more stabilizing political orders of the Ottoman Northwest, the 'Turkish' Southwest, the Turkmen North and the Timurid East. In the latter statist contexts especially, leaders continued to pursue a more coherent administrative level of integration and central control through the enforcement of particular regulations, such as the temporary and non-hereditary allocation of prebendal grants, the assignment of territorially dispersed prebendal lands, the rapid transfer of grant holders between estates, or alternative remunerations from central repositories. However, centrifugal tendencies to subvert these regulations remained equally strong, as in the waqf-ization process, as well as more generally in the atomistic and diverse practical organization of the management of grants, tax farms, tributes, endowments and estates. For this reason, the costs of enforcing these regulations for central authorities often proved extremely high. As a result, rulers and elites throughout fifteenth-century Islamic West-Asia continued to favor a diversity of ad hoc and middle-ground solutions serving a variety of local and centralizing needs and interests, even in the increasingly stable contexts of the SyroEgyptian and Ottoman Sultanates. ${ }^{18}$

Overall during this period, these devolved, segmented and negotiated ways of organizing fiscal relationships were actually part and parcel of the rather light and messy wider arrangements that accompanied the political fortunes of the region's Turko-Mongol rulers, dynasties and power elites. Just like redistributive practices, these organizational arrangements throughout the region were rooted in various hazy combinations of longstanding bureaucratic precedents, local managerial requirements and particular types of expertise and opportunity. Basically, every man of status and every leader high or low had to find his own solutions to the challenges of collecting and paying his dues, of communicating with sovereigns, peers and subordinates, and of safeguarding his patrimony. Across the region, solutions to these challenges were largely

18 Inalcik, "Autonomous Enclaves in Islamic States"; Inalcik's attempt to create a better sense of the meanings and roles of "Temliks, Soyurghals, Yurdluk-Ocaḳlıks, Mâlikâne-Mukātạas and Awqā $f^{\prime}$ certainly leaves the reader with this impression of diversity and ad hoc solutions. 
determined by local circumstances, as well as by regional and historical conditions, and, above all, by the sliding scale of a man's power. Here, both personalized politics and volatile political realities defined the level of complexity of organizational challenges and their solutions as well as, importantly, the composition, size and fate of the administrative and military staff supporting a leader in his duties.

Everywhere, relationships of power, whatever their level of complexity and authority, coalesced around basic organizational units of groups of people bound together through multivalent sets of personalized ties. As in preceding centuries, these bonds ranged from various kinship arrangements to mutual loyalties acquired through social action. As far as the diverse Turko-Mongol leaderships of fifteenth-century Islamic West-Asia are concerned, there was a range of more or less structured formats in which these organizational units of people and social ties could appear, depending on a man's power. Peripatetic warbands of military leaders and their associates and personal retainers were one, often more short-lived, format that continued to make its mostly violent appearance in particular in Islamic West-Asia's frontier zones and peripheries. Urbanized households of sultans, princes, courtiers and their personal bodyguards, women, children, servants and administrators were another, heavily structured format, occupying the other extreme on this continuum of core relationships of power. ${ }^{19}$ In the devolved, segmented and negotiated realities of fifteenth-century Islamic West-Asia, most relational power constellations wavered in dynamic ways between these two extremes of social complexity. As suggested above, only a handful of these constellations attained and maintained a high level of organizational complexity, transforming with varying levels of success into the region's central courts in Cairo, Constantinople, Tabriz, Herat and Samarkand.

Throughout Islamic West-Asia, scribes (Ar. katib, pl. kuttab) of various provenance and expertise were hired to perform duties of tax collection, of household and military expenditure, and of letter writing in Arabic and Persian (and, increasingly, Turkish) for these diverse power constellations. Whenever, and wherever, the scale of a patron's power required it, specialization and diversification generated, or regenerated, more complex administrations. This process involved the structuration of larger sets of scribes and their different tasks following the ancient bureaucratic unit of the diwan and along hierarchies topped by traditional positions such as that of the vizier (Ar. wazir) or its Persian or Turko-Mongol equivalents. Similar processes affected the military entourages

19 Crossley, "Military Patronage and Hodgson's Genealogy of State Centralization in Early Modern Eurasia", pp. 105-108. 
of West-Asia's rulers and leaders, with each patron having in their service fighters of various provenance and expertise ranging from tribal levies over mercenaries to military slaves and freedmen, and from horsemen to footmen. The occasional expansion of these fighters' ranks also led these services to specialize, diversify and subscribe to structural military precedents, including that of hierarchies of commanders known as amirs (in Arabic and Persian) or begs (in Turkish). In the course of the fifteenth century, as will be detailed below, this process of growing organizational complexity marked the history of Ottoman, 'Turkish' and Timurid leaderships and their courts in Western Anatolia, Egypt and Eastern Iran. It also happened to a certain extent in the entourages of other powerful leaders in the more unstable and peripheral frontier zone that connected Eastern Anatolia, Iraq and Azerbaijan.

In Egypt, as elsewhere in West-Asia, this process of bureaucratic specialization and diversification had actually been ongoing with ups and downs for several centuries. Following long-standing regional traditions of Arabic writing on epistolary and accountancy practices, this process' trajectory during the fifteenth century, in the service of the 'Turkish' Sultanate, was captured and reproduced in a handful of very detailed and informative literary texts. Describing the rules and regulations of the Sultanate's court and power apparatus, these books were written by scribes as manuals and as instruments both of the Sultanate's bureaucratic practice and of that practice's structural coherence across time and space. In these literary repositories of fifteenth-century protocol and epistolary modelling the Sultanate's apparatus actually appears as far from light. Indeed, these texts rather portray a powerful and coherent bureaucratic structure set up to penetrate and organize local power relationships as efficiently as possible. This impressive contemporary appearance has substantially informed many modern imaginations about the Sultanate, painting a picture of a highly rationalized bureaucratic state, organized and performed along a neatly devised triple hierarchy of 'the men of the sword, the men of the pen and the men of the turbans'. In modern scholarship, these contemporary categories are generally referred to as the 'military-executive', the 'financialsecretarial', and the 'judiciary office holders' of 'the Mamluk government'. ${ }^{20}$ Furthermore, in modern Ottoman studies there is an equally widespread tradition to understand the Ottoman Sultanate in the later fifteenth and sixteenth centuries as a similarly intrusive bureaucratic state. This mainly followed from the fact that from the early sixteenth century onwards, this state began to leave an impressive paper trail not just in comparable manuals and administrative

20 Popper, Egypt and Syria under the Circassian Sultans, pp. 90-110. 
repositories, but also in uniquely preserved archival records. In fact, variations of this bureaucratic type of state appeared for a long time as a norm in modern scholarship that could be used to understand, evaluate and compare political organizations across fifteenth-century Islamic West-Asia, especially in Egypt and West Anatolia and to some extent also in Timurid Khurasan, as more or less successful prequels of the region's early modern empires.

As will be detailed in the next chapter, since the early 199os some scholars are also pointing to the pitfalls of teleology and anachronism in argumentations such as these, and alternative interpretations of the actual nature and meaning of bureaucratic practice and of bureaucratization in a context of Turko-Mongol politics are gradually being formulated. Considering the violent, volatile and personalized nature of those politics across the region, including in fifteenth-century Egypt, current scholarship is now certainly also contemplating the possibility that administrative texts and political realities could be two very different things. Indeed, the former texts may well have been one of the tools available to scribes and to their patrons to pursue more stable participation in, and control over, the fluidity of the latter realities in the face of continuous challenges. This approach tallies not just much better with what is known about fifteenth-century Turko-Mongol politics, but also with data from many other contemporary sources which points to the often incoherent and ad hoc nature of bureaucratic practice and also hints at the rather more limited success of central bureaucracy's penetration of local communities across fifteenth-century Islamic West-Asia. As suggested by the competitive nature of Turko-Mongol organizational arrangements, the structural integration of elites in centralizing sets of relationships was frequently contested, and the integration of diverse local and regional administrative practices and actors in centralizing claims to authority remained a haphazard enterprise. Wherever in Islamic West-Asia the scale of a leadership's power enabled administrative and military specialization and diversification, physical and political distance nonetheless continued to define, and confine, the extent of a locality's bureaucratic penetration by the center and its organizational arrangements. Just as with the politics of fiscal administration, the administration of central authority in this wider sense also continuously intersected and competed with all kinds of local, alternative or rival authority arrangements. The combination of a need for costly investments of people and resources to face these challenges, alongside the infrastructural limitations of surveillance and communication, and also the volatility of Turko-Mongol politics and the recurrent recalibration of central powers in fifteenth-century West-Asia, all meant that substantial distances continued to separate political actors. All this reflects above all a historical reality of socio-political segmentation and of local continuity and 
empowerment that was not easy to integrate into, let alone control with centralizing bureaucratic arrangements, ambitions and apparatuses.

In fact, as suggested by Manz' archipelago metaphor above, West-Asia's integration into the orbits of its main political centers in the fifteenth century remained a contested and diverse reality which often involved the ad hoc action of military agents and local representatives. Irrespective of West-Asia's diverse ecological systems, administrative penetration and integration were therefore primarily limited to the main urban centers and towns and their hinterlands and to the upholding of interrelated, but also locally accommodated, urban systems of taxation and justice. This urban prioritization can be seen most forcefully in the concentration of military and administrative representatives and agents of central courts, as governors, commanders, judges, scribes and tax collectors, in many of the urban centers and towns of Egypt, Syria, Anatolia, Armenia, Azerbaijan, Iraq, Iran, Khurasan and Transoxiana. As explained before, this presence had a mixed impact on local relationships of power, depending on distances and loyalties, on central investments of expensive resources, and on all kinds of different local complexities. Wherever any urban penetration was achieved, however, the core business of any political apparatus was to focus on tapping into local resource flows via fiscal and other arrangements, the maintenance of social order to assure the steady flow of those resources, and at best also some local performance of the central court's claims to sovereignty and political order.

Any assessment of the nature of this central penetration of local relationships of power is complicated by not just the structuring bias of Arabic, Persian, and Turkish administrative textbooks, but also the general paucity of documentary and non-urban sources for the political history of fifteenth-century Islamic West-Asia. Towards the end of the fifteenth century, however, another important set of bureaucratic texts emerged in Aq Qoyunlu and Ottoman contexts. These texts confirm in many ways this rather narrow bureaucratic focus on local urban systems of taxation and justice as outlined above. The sources in question are the interrelated Law Books (Kanun Name) of Uzun Hasan and of the Ottoman sultan Bayezid. ${ }^{21}$ As Ottomanist Rhoads Murphey explains for the latter case, these and a related handful of surviving documents and texts confirm indeed that

it was from the narrow base of the more closely regulated urban space and urban markets that the Ottomans launched their first and most effective efforts aimed at modifying undesired market tendencies such as

21 Imber, The Ottoman Empire, 1300-1650, pp. 244-251; Woods, The Aq Qoyunlu, pp. 108-109. 
hoarding and price speculation, and at creating the basis for a fair balance between mercantile profit and affordability for average urban consumers. ${ }^{22}$

These Law Books integrated various local customary arrangements, complementing more general doctrinal regulations and legal advice formulated by specialists of religious law who tended to operate within alternative authority frameworks. As such, these Law Books announced comprehensive regulatory codification projects of later Ottoman sultans, but certainly did not mirror them. They actually pursued a more active central participation in particular local social, commercial and fiscal arrangements and solutions by proscribing and regulating the agency of the ruler's own local agents and representatives. The production of these specimens of royal codification towards the end of the fifteenth century are therefore above all rare extant functions of the growth, specialization and diversification of the entourages of Uzun Hasan and Bayezid as these were trying to organize the expanding horizons of these rulers' power.

In this way these Law Books actually only represent one particular moment in the formation and empowerment of such entourages and political apparatuses. Similarly formalized communication between courts and their agents in the form of decrees, orders, diplomas, missives, letters and reports-most of which have not been preserved - were integral to bureaucratic expansion throughout fifteenth-century Islamic West-Asia, performing political authority as much as negotiating it. Other equally important aspects of this growth and expansion included all kinds of regulatory efforts, including the maintenance of social order and the ensuring of justice, related both to fifteenth-century West-Asian rulers' symbolic apparatus as well as the daily performance of their claims to sovereignty and resources and therefore often recorded in contemporary narrative texts of history. Modern scholarship has even made the convincing case regarding the Syro-Egyptian Sultanate that the ruler and his bureaucratic agents managed to appropriate legal and judicial authorities traditionally only invested in more autonomous specialists of religious law. ${ }^{23}$ This remarkable expansion of the authority of the sultan of Cairo and of his bureaucratic apparatus appears not to have been achieved by any other ruler in fifteenthcentury Islamic West-Asia. Nevertheless, many certainly also deployed, or

22 Murphey, "The Ottoman Economy in the early imperial age", pp. 28-30, esp. 28.

23 Rapoport, "Royal Justice and Religious Law". 
pursued, similar strategies of growth, penetration and judicial empowerment in their own, more or less successful, ways. ${ }^{24}$

\section{Situating Trajectories of State Formation in Islamic West-Asia}

In the wide range of predominantly urban bureaucratic practices, fifteenthcentury leaders and their agents generally seem to have prioritized concerns for power and control over any expectations about the performance of government and of specific administrative tasks. ${ }^{25}$ This prioritization involved first and foremost the power, control and level of local or regional participation of the leader or ruler in whose service an administrative and military apparatus operated. However, in many, if not all, cases it also involved the power and control that could be acquired by the bureaucrats themselves, and that could be wielded by scribes, by military commanders and by all kinds of other agents in the leader's service. Closeness and direct service to the ruler in varieties of advisory, financial, military, diplomatic, ceremonial or other capacities were certainly one strategic means by which an agent could acquire power and control, indeed this was a very important tool amidst the returning realities of Turko-Mongol personalized politics. But in certain political contexts, these capacities could also be transformed into power and control in other, more autonomous, and therefore also more structural ways. Whenever the scale of a leadership's political reach in fifteenth-century Islamic West-Asia enabled bureaucratic specialization and diversification, this also generated a lengthening of the virtual chains of authority and agency between a ruler and the increasing numbers of agents performing his rule. From these agents' perspective, with greater complexity thus also came a relative depersonalization of the ties that bound them to their ruler. This was accompanied by the transformation of the ruler from a mere powerful person into a more abstract idea and representation of correct political order. This form of state formation therefore brought

24 See Burak, "The Second Formation of Islamic Law", for a wider, comparative consideration of the relationship between Turko-Mongol dynasts and Islamic law in the late medieval and early modern period, suggesting that "different dynasties' adopting a particular Islamic school of law as their official state school [...] [represented] active attempts by the ruling dynasty to regulate the school's structures, authorities, and doctrines" (p. 580) and that at least in the Ottoman case this process of expansion of dynastic authority began in the early fifteenth century and is especially notable from the sixteenth century onwards.

25 Miura, "Administrative Networks in the Mamluk Period"; see also Chapter Two in this volume, especially "Introduction: Defining the 'state' between Max Weber, 'Abd al-Rahman Ibn Khaldun, and Charles Tilly". 
greater autonomy for those along the chain who were trained, skilled and experienced in the maintenance, reproduction and expansion of that order, resulting in a remarkably symbiotic interaction between an agent's own empowerment and that of the leadership he served. ${ }^{26}$

As suggested before, this classic state formation process of the mutual empowerment of a bureaucratic apparatus and of a centralizing political order topped by a particular leadership emerged especially in fifteenth-century Islamic West-Asia in the Ottoman Northwest, the 'Turkish' Southwest, the Timurid East and eventually also the Turkmen North. In each of these particular leadership contexts it did so only in qualified and circumscribed ways, as trans-regionally competing (and hence also co-constitutive) phenomena that were predominantly urban-centered realities and that were continuously challenged, intersected and renegotiated. Furthermore, the different leaderships of the more peripheral frontier zone in between these stabilizing political spaces also experienced an overlapping variety of more and less parallel moments of symbiotic empowerment. In all regions, military successes and expansions led by Turko-Mongol leaderships certainly generated some form of bureaucratic growth, diversification, specialization and state formation. In many cases, however, the same kinds of ongoing military action could also easily thwart this process of central or regional consolidation, and cause its regular regression to more personalized and contested relationships of power.

Having considered the general contours of fifteenth-century Islamic WestAsia's politics, its power elites and its Turko-Mongol practices and institutions, let us now turn to a more specific interpretation of these patterns of state formation and transformation, in particular of the dynamics that appear to have defined these patterns throughout this long century in the Ottoman, SyroEgyptian and Timurid-Turkmen contexts. The main historical dynamics that will be discussed here reflect convergences of key features of West-Asian state formation that distinguish the fifteenth century while at the same time marking its trans-dynastic entanglement. These include the contingency of centralizing longevity, the integration of distant power elites through multivalent processes of bureaucratic growth, the specificity of elite renewal by outsiders to West-Asian political realities, and the reproduction of central bureaucratic elites in highly competitive as well as parallel and continuous ways.

\subsection{The Politics of Longevity}

In the Ottoman, 'Turkish' and Timurid-Turkmen contexts, one of the main factors that tended to check the fragmentation of power constellations so typical

26 Van Steenbergen, Wing \& D'hulster, “The Mamlukization of the Mamluk Sultanate?”. 
of Turko-Mongol politics was the contingency of an easily forgotten phenomenon that will be named 'centralizing longevity' here. Fully in line with the nature of Turko-Mongol politics, it actually was a personalized type of centralizing longevity that seems to have generated almost paradoxically more depersonalized processes of bureaucratic diversification, specialization and state formation in most of fifteenth-century West-Asia's political centers. This type concerned the longevity of personal rule, when a ruler's military and political successes were long-lasting, over time generating the appearance of his reign as pertaining to a natural order of things. This longevity of personal rule created a charismatic political authority that somehow transcended and contained recurrent warfare and fragmentation while at the same time stimulating bureaucratic growth and state formation. Between 1421 and 1512 the Ottoman Sultanate was led by just three powerful rulers, who each reigned successively for some thirty years: Murad (r. 1421-44, 1446-51), his son Mehmed (r. 1444-46, 1451-81) and his grandson Bayezid (r. 1481-1512). This remarkable continuity of leadership was certainly one of several factors that facilitated a more or less persistent symbiotic interaction between these rulers' empowerment and that of new groups from their expanding, diversifying and specializing entourages. There occurred similar continuities and processes of symbiotic interaction, gradual empowerment and bureaucratic growth in Timurid contexts, especially during the long reigns of Shah Rukh (r. 1409/1416-47) and then of Sultan-Abu Sacid (r. 1451/1459-69) and Sultan-Husayn Bayqara (r. 1469-1506) in the East. To certain extents, these multivalent phenomena of Turko-Mongol state formation eventually also accompanied various other Turkmen experiences of long, successful and expanding personal rule, such as with the Qara Qoyunlu ruler Jahan Shah (r. 1439-67), with his Aq Qoyunlu successor Uzun Hasan (r. 1457-78) or with the Karamanid Ibrahim Beg (r. ca. 142364). The fifteenth century in Islamic West Asia was thus certainly an era marked by both a remarkable set of long reigns and a variety of processes of state formation at the same time. Unlike in the Ottoman case, however, Turkmen, Karamanid and even Timurid forms of state formation in West-Asia's frontier zone never entirely managed to contain the detrimental effects of Turko-Mongol politics. The persistence of bureaucratic staff and practices certainly ensured some forms of stability, continuity and state formation in the face of the violent dynastic transitions from Shah Rukh to Sultan-Abu Sacid and then Sultan-Husayn or to Jahan Shah and then Uzun Hasan in Iran and Azerbaijan, and from Karamanid to Ottoman sovereignty in Southern Anatolia. Nevertheless, such transitions after the disappearance of strong leaders were also always marked by the radical fragmentation, subordination or even annihilation of Timurid, Turkmen or Karamanid political authorities and power elites. 
In contrast, this never happened in any similarly destructive ways within the Ottoman dynasty or for the Syro-Egyptian Sultanate in the fifteenth century, at least not after the first years of the century. Following Temür's violent passages, these years had in both cases indeed been marked by a similarly radical loss of political authority, central control and coherence. In Cairo a kind of centripetal institutional force actually enabled the containment and then, throughout the fifteenth century, the stabilization and structuration of this recurrent centrifugal dynamic in the format of the Sultanate's own successful trajectory of state formation. In the course of their long careers of military service, resource building (including through waqf-ization) and political leadership, the aforementioned successive sets of fifteenth-century state actors in Cairo decided successions to the sultanate and could even themselves rise to that position. As such they were both the products and the performers of that trajectory of continued bureaucratic growth, centripetal empowerment and political structuration, as Kristof D'hulster also suggests in Chapter 3 of this volume. At the same time the Sultanate's political elites, including these actors, continued to face regular and violent fragmentation in the context of succession struggles and other variants of Turko-Mongol internecine warfare. Unlike what happened among their Timurid or Turkmen peers, however, between 1412 and 1517 this never had any similarly destabilizing effects in the Sultanate on its territorial or socio-political coherence. This remarkable situation of bureaucratic growth and state formation in the face of endemic political violence and conflict in many ways was both a result and also a contributing factor of a kind of institutional inertia. This inertia was above all informed by the institutional longevity of the Sultanate in Cairo, which was unique, at least for fifteenth-century West-Asia. The Sultanate in Cairo originated with the Muslim championships of Saladin in the later twelfth and of a handful of mamlük sultans in the thirteenth centuries and, as a site of trans-regional power, arguably even with their predecessors in Cairo since the tenth century. It was this institutional longevity and subsequent inertia that stimulated, irrespective of any divergent realities, the reproduction of the coherent, timeless and natural appearance of the Sultanate's political order in the aforementioned administrative texts as well as in all kinds of other contemporary imaginations and performances.

Nowhere else in post-Temür Islamic West-Asia were there any similarly longstanding and awe-inspiring continuities in Muslim sites, institutions, values and resources of power that could be claimed to complement and consolidate recurrent moments of personal centralizing longevity and its structuring effects on relationships of power. Nevertheless, all the fifteenth century's Turko-Mongol leaderships regularly, and successfully, appealed to ideas of institutional continuity with local or regional Turko-Mongol, Perso-Islamic and 
other precedents. However, in the Ottoman case only the returning instability of Turko-Mongol political practices was also contained by another form of institutional longevity, contributing to a specifically Ottoman trajectory of state formation. This trajectory arguably only really took off when, after the conquest of Constantinople in 1453, another powerful type of centripetal institutional inertia started contributing to the effects of many years of successful Ottoman leadership. For sultan Mehmed and his successors, the ancient imperial metropolis of Constantinople, with its wide-ranging appeal to political, cultural and socio-economic imaginations on an incomparable Eurasian scale, soon proved a structuring site of power that rivaled Cairo's role, both as a stabilizing centripetal factor within the Sultanate and a valuable regional metropolis at the pinnacle of Islamic West-Asia's hierarchies of power. Ottoman political authority continued to face ongoing disruptive political challenges, such as the threat posed between 1481 and 1495 by sultan Bayezid's brother, the refugee contestant for the throne Jem Sultan, or the struggle for succession between Bayezid's sons Korkud, Ahmed and Selim between 1511 and 1512. Yet during all this time, the Ottoman political order and its expanding number of agents, proved more than capable of securing the appearance of coherent political continuity and of avoiding the fate of Timurids, Karamanids or of many other Turkmen dynasties.

\section{2 $\quad$ The Politics of Distant Integration}

Whether cut short by the disruptive realities of Turko-Mongol politics or sufficiently embedded through different types of longevity to survive any such disruptions, there were various trajectories of state formation that made a marked contribution to the political landscape of fifteenth-century Islamic West-Asia. Above all, these trajectories with their differing institutional qualities and quantities brought various levels of political autonomy to those involved in the region's complex chains of authority and agency, including to all kinds of non Turko-Mongol and non-military elites. In many areas of WestAsia, state formation thus offered a channel to integrate, in more than merely coercive ways, extant local political, administrative and military elites and elite arrangements into the expanding order of a successful center of Turko-Mongol power. It is all too easy to forget this phenomenon of the distant, occasionally resource-intensive and violent, and mutually-empowering integration of local leaderships into the bureaucratic apparatus of fifteenth-century West-Asia's more successful political orders. These different local elites and the politics of their political integration are equally important aspects of the trajectories of state formation in fifteenth-century Islamic West-Asia. It is therefore relevant to consider them here in some more detail too. 
As mentioned before the process of political structuration through bureaucratic growth engaged various urban elites in particular within expanding power relations of a centripetal and simultaneously locally accommodated nature. From Cairo and Alexandria in Egypt and Gaza, Jerusalem, Damascus, Homs, Hama, Tripoli and Aleppo in Syria, and from Bursa, Iznik, Sinop, Konya, Ankara, Amasya, Sivas, Kayseri and Amid in Anatolia and Tabriz, Mosul, Baghdad and Basra in Azerbaijan and Iraq, to Isfahan, Yazd, Shiraz, Kerman, Herat, Samarkand and Bukhara in the regions of Iran, Khurasan and Transoxiana, West-Asia's diverse and fragmented urban realities were not only dominated by interrelated and competing local and regional social formations and their overlapping varieties of kinship, communal identity and professional specialization. The arenas of intense social interaction which gave birth to these and many more urban centers and towns in West-Asia's ancient urban networks were also shaped by more or less successful attempts at urban participation through bureaucratic expansion and integration by various, often competing, Turko-Mongol power centers. ${ }^{27}$ Again, the urban penetration of these centers in this manner was extremely diverse and multivalent across time and space, defined by physical and social distances as well as by sliding scales of TurkoMongol power and success. Moreover, even where that penetration was most successful, not all urban groups were necessarily touched by it in the same way, and not all local urban elites, including Coptic accountants in Egypt, administrative experts from various sectarian communities in Syria, Anatolia and Iraq, or Persianate scribes and scholars across West-Asia, were necessarily similarly transformed into bureaucratic agents of a political center's interests. However, as also suggested by Patrick Wing's and Georg Christ's case studies of different merchant families and communities in Part 3 of this volume, many local actors went through an integrative process such as that of state formation and thereby became more deeply involved in the era's expanding political orders. Some certainly also became active shareholders in those political orders, as upholders of longstanding specialist solutions at the same time as being local or even regional political leaders.

Parallel to these urban technocrats and notables, Islamic West-Asia's rural and tribal elites were also in one or another way affected by the fifteenth century's trajectories of state formation. Actually, along the many, constantly changing, fringes of the century's intricate political orders many figures, including all kinds of Arab, Turkmen and other tribal leaderships and marsher 
lords, chose to be integrated into the bureaucratic apparatus of a political center in order to both contribute to the idea of the trans-regional expansion of that center's political order and to generate local distinctions through the social power of trans-local titles, paraphernalia and connections. Military service in particular continued to generate power in all trajectories of state formation, but the wider the distance separating these local military agents from the expanding political center, the more symbolic any obligations related to that service were, and the more local and centrifugal their power was. The atomistic, segmented and fickle realities of power relationships across fifteenth-century West-Asia, and the urban bias present in the more successful trajectories of state formation meant that such political distances with (semi-)nomadic leaderships in particular remained substantial. As a result, local instrumentalizations of any form of integration into the bureaucratic growth of regional centers-including also various arrangements that favored new leaderships, or new parties within extant leaderships-often prevailed over any more centripetal dynamic and over any form of bureaucratic penetration. Across the board such penetration was at times still considered necessary, particularly in ad hoc contexts of disputes over taxation and tribute, in the face of safety issues concerning the circulation of goods and people, and when there were changes to the perceived balance of trans-regional powers. In these cases, penetration mostly happened in the format of diplomatic exchanges and punitive expeditions which aimed to restore the local appreciation of a center's coercive power and to recalibrate its troubled relations with local elites. However, these exchanges and expeditions always represented occasional, temporary and expensive investments of financial and human resources in the intensification of particular sets of political relationships, and as such these missions and expeditions into West-Asia's diverse rural and nomadic areas always remained hazardous enterprises, at best generating only uneven and transient outcomes. Sometimes they even contributed to the empowerment of new local groups and individuals, and often carried within them the seeds of subsequent expeditions. Throughout the century and the region, they never gave way easily to more systematic reductions of political distances or to wider structural forms of integration in the state apparatus. ${ }^{28}$

28 For examples of this phenomenon, see Wing, "Submission, Defiance, and the Rules of Politics"; Garcin, "Note sur les rapports entre bédouins et fallahs". On these atomistic and also distant power relationships across fifteenth-century Islamic West-Asia, see furthermore the (very different) local examples engaged with in Binbaş, "Did the Hurufis Mint Coins?" (for the Anatolian region of Erzincan) and in Walker, "The 'Disappearing' Villages of Late Medieval Jordan" (for the Transjordanian region in Southern Syria). 
This type of distant, occasionally resource-intensive and violent, and mutually empowering integration of local leaderships into the bureaucratic apparatus of fifteenth-century West-Asia's more successful political orders was decisive for political relationships above all in the poly-centric zone that stretched from Azerbaijan and Iraq to Anatolia. It marked the unsteady political relationships that connected many petty lords and rulers in this more peripheral zone to the competing trans-regional trajectories of Ottoman, 'Turkish' and Timurid state formation. As John Meloy reminds us in his contribution to Part 3 of this volume, this was also true for the elites of the Hijaz on the Arabian peninsula, controlling the sacred centers of Mecca and Medina both in the name of the Sultan of Cairo and as powerful but contested patrons of local communities. ${ }^{29}$ In the second half of the fifteenth century, the Timurid disappearance in Western Iran and the trans-regional empowerment of Jahan Shah Qara Qoyunlu and then Uzun Hasan Aq Qoyunlu, obviously re-oriented many relationships. Nevertheless, Eastern Anatolia in particular remained a genuine frontier zone, where trans-regional authorities were disputed, where political distances appeared as substantial, and where ambitions to stabilize or even structure political relationships continued to be resource-intensive and hazardous enterprises. Important moments here include the decisive victory of the Ottoman sultan Mehmed over Uzun Hasan in 1473 at the battle of Bashkent in the Anatolian East and the Ottoman conquest of the Karamanid capital of Konya in the South in 1468. These would prove key moments for the particular transformation towards a more structural Ottoman penetration of Anatolian power relationships. ${ }^{30}$ Nevertheless, Karamanids, their local tribal supporters, Aq Qoyunlu followers and many other Anatolian groups continued to challenge and subvert that penetration after the end of the fifteenth century, as did competitors for trans-regional authority from Cairo and Tabriz. In fact, the hugely expensive and mostly ineffective military confrontations between 1485 and 1491 in Southern Anatolia between the troops of Mehmed's successor Bayezid and those of the Sultan of Cairo, Qaytbay, were very much an illustration, a product and a confirmation of those Anatolian frontier conditions. ${ }^{31}$ In many ways, therefore, throughout the fifteenth century the disputed politics of local state formation and distant integration persisted in Southern and Eastern Anatolia, as they did in the regions of Iraq, Iran and Azerbaijan, at least until the beginning of Turkmen trans-regional empowerment with Jahan Shah Qara Qoyunlu.

29 See also Meloy, Imperial Power and Maritime Trade.

3o Ylldız, "Razing Gevele and Fortifying Konya".

31 Har-El, Struggle for domination in the Middle East. 
Closer to West-Asia's main centers of political power, especially in nonurban contexts the political distances from local leaderships often equally remained substantial. This could be due to geographical circumstances hindering easy access to a nearby region or to the Turko-Mongol practice of regular political fragmentation obstructing stable relationships with local power elites, amongst other possible more local variables. In all of these contexts of wider social distance, various forms of these particular politics of distant integration also persevered in Western Anatolia, in Syria and Egypt, in Azerbaijan and in Eastern Iran and Transoxiana, despite the more successful trajectories of state formation in operation in and beyond those regions. Arab and Turkmen Bedouin, Anatolian tribal and rural associations, Iranian mountain dwellers and many more groups participated actively in local and, occasionally, regional politics. Across Islamic West-Asia, and across these different social formations, these politically relevant groups and people also included trans-local communities of scholars, mystics and their followers in largely unprecedented ways, with people often rallying around charismatic religious leaders and driven by heterodox and occultist ideas and apocalyptic fervor. ${ }^{32}$ The actions of these groups had great political relevance on the local or even regional scale, and throughout the fifteenth century they therefore often informed central reports that either marked these groups as brigands and outlaws, as loyal state agents, or as both. These groups' political actions often indeed countered or subverted state formation trajectories, causing endless conflicts and disputes. Alternatively, such conflicts were equally often instigated by the different expectations and opportunities raised by the fiction of any attempts at these groups' distant integration into such trajectories. Besides such efforts, mainly in the form of diplomatic exchanges, at mutually beneficial integration into the military and administrative apparatus, central powers mostly resorted to costly punitive expeditions as their main mechanism for resolving these recurrent tensions with Bedouin and other nomadic and rural interests, or dealing with subversive

32 Binbaş, Intellectual Networks in Timurid Iran. Binbaş actually argues that substantial diachronic change defined the space for political participation for networks of intellectuals, scholars and men of religion in the course of the fifteenth century, suggesting on the one hand that the state formation processes in the Ottoman Northwest and Timurid East of West-Asia in particular integrated such loosely defined networks more effectively from the mid-century onwards. On the other hand Binbaş believes that those same processes simultaneously empowered more complexly organized networks of Sufi masters and followers as active partners and agents and eventually as rivals, with the Safawiyya Sufi brotherhood and their Eastern-Anatolian Turkmen supporters transforming into the Safavid imperial polity. 
ideas and claims. Even in the more directly administered environments of the Ottoman Northwest, the 'Turkish' Southwest, the Turkmen North and the Timurid East, most attempts at more structural integration and control still quickly proved too resource-intensive to maintain for any states in formation during this time. It was only in the Ottoman North that this mutually constitutive wavering between an accommodated and a violent integration of local, centrifugal power relationships sometimes acquired a more structured outlook. This phenomenon was apparent in the practice of moving certain, subversive, Anatolian populations and social groups to new regions, especially across the Bosporus. There, as local outsiders, their fortunes were more intimately linked to that of the trajectory of the Ottoman state in their new roles as economic and military agents of that state. This Ottoman practice of collective resettlement (sürgün), achieved through a combination of violent coercion and the award of economic privileges, manifested itself most famously between 1468 and 1473 in the repopulation of the new capital of Constantinople with people from the South-Anatolian Karamanid lands. A powerful tool in the particular trajectory of Ottoman state formation, however, in the fifteenth century it remained simply an ad hoc solution to particular problems of distant integration just like any other that was available to the Ottoman sultans, and to their West-Asian peers.

\subsection{The Politics of Central Elite Renewal: mamluks, kul, and Turks}

Islamic West-Asia's multivalent trajectories of Turko-Mongol state formation generated multiple new opportunities not only for the empowerment of ancient or distant local groups and elites. These trajectories also interacted along mutually defining pathways with all kinds of other social formations of more recent stock and specialization, similarly complementing or even joining the ranks of the Turko-Mongol leaderships of the post-Temür era at the very cores of its political centers. The complete integration of political, military and even social outsiders as new power elites was nothing new in the histories of Islamic West-Asia. However, as will become clear below, in the fifteenth century this happened with a variety, range and to an extent which were quite unprecedented, and therefore deserving of separate discussion, if only for the way they further illustrate the particular trajectories of Islamic West-Asian state formation.

In the final quarter of the fourteenth century, Temür's enterprise sought to use a politics of endless conquest to create a new trans-regional West-Asian power elite composed of his family and of his comrades-in-arms, most of whom stemmed from minor leaderships in the Chagatai nomadic conglomerate of Central Asia. This radical social transformation thus generated the nucleus of 
the fifteenth century's Timurid leaderships. ${ }^{33}$ Temür was continuing longstanding practices accompanying the establishment of new Turko-Mongol leaderships, and his achievement in replacing more traditional, structured power relationships with entirely new, personalized ones was, as explained before, regularly repeated across West-Asia as part of Turko-Mongol tanistry and appanage practices. In Timurid and Turkmen contexts, however, these regular shifts never entirely repeated Temür's exploit of the creation of a radically new central elite at the turn of the fourteenth to fifteenth centuries. The East's political centers of Tabriz, Shiraz, Herat and Samarkand continued to be dominated by Temür's military elite of Turko-Mongol powerholders as well as their Turkmen peers of more traditional leadership origins. This happened above all in an uneasy, mutually restrictive interaction with the particular trajectories of state formation that developed around long-reigning successful rulers such as Shah Rukh, Sultan-Abu Sacid, Jahan Shah, Uzun Hasan, and Sultan-Husayn. Regularly partaking in the expanding political and military apparatuses around these rulers and their courts, these military elites were collectively identified as one exclusive political community of 'Turks', even though their ranks remained divided by violent competition and internecine warfare, and by political action undermining and disrupting as much as supporting those trajectories of state formation. There were regular endeavors to introduce fuller integration or even the marginalization of these centrifugal 'Turkish' military elites but these attempts at strengthening particular central state formation trajectories were never entirely successful in disciplining the era's Turko-Mongol tide of devolved authority and recurrent fragmentation. As a result, from Temür's time onwards, Timurid, Turkmen and Turko-Mongol military leaders, families and lineages continued to hold on to their access to authority, power and income across these regions, pursuing interests that never easily aligned with those of their sovereigns, and continuously negotiating balances of power that everywhere checked the political autonomy of these 'Turkish' amirs as well as of Timurid and Turkmen rulers and princes.

In the contexts of the Ottoman and 'Turkish' Sultanates, on the contrary, feats similar to Temür's creation of a new elite appeared in more systematic ways than ever before, and can arguably even be seen as important functions of these Sultanates' particular trajectories of state formation. The historical trajectory that, in modern scholarship, tends to be most intimately connected with this notion of a socio-political reproduction through the repeated recreation of Turko-Mongol elites is that of the Sultanate of Cairo in Egypt and Syria, today also known for this reason as the Mamluk Sultanate. For centuries the personal armies and warbands of rulers and leaders in Egypt and Syria had 
been constructed around the skills and capacities of hardened horsemen. Most of these horsemen were brought to the region in unfree (mamluk) conditions via commercially vibrant commodity chains especially from Inner Asia's steppes and the Caucasus, to be subsequently prepared for military and political service in their new master's entourage. Throughout this long period, but especially since the mid-thirteenth century, many individuals originating as mamluks managed to acquire local or regional power and leadership, building up their own armies of mamluks, and occasionally even attaining the sultanate. As mentioned before, in the post-Temür fifteenth century amirs and sultans with diverse mamluk origins emerged more consistently than ever before as actors and agents of the Sultanate's state. Collectively identified in contemporary communication as both Circassians (Jarakisa) and Turks (Atrak) at the same time, almost all of these sultans and amirs had been among the tens of thousands of mamluks who, throughout the century, were sold in Egypt, reeducated as Sunni Muslims, trained as Turko-Mongol horsemen, accustomed to speaking Qipchaq Turkic, and accommodated to Turkic patterns of martial behavior. New groups of these Turkified Circassians regularly rejuvenated the ranks of a sultan's personal troops in particular, to strengthen his military capacities, to counterbalance those of his mamluk military commanders, the amirs, and to expand the pool of military experts available for him to rely on and to favor in return with rank, status and income. The Sultanate's political elites of 'Turkish' amirs therefore all shared similar individual histories of mostly (non-Turkish and non-Muslim) Caucasian origins, juvenile enslavement and transfer, long years of royal military and court service and of resource building, and endless competition for status and income with regular batches of new royal favorites of similar backgrounds. In fact, in this process of highly competitive social reproduction amidst the expansion of the sultan's bureaucratic apparatus and the lengthening of its chains of authority and command, not just particular sets of mamluk amirs-courtiers, but also groups of the sultan's mamluk rank-and-file in Cairo appear to have acquired more political autonomy than ever before. In any case, the unruly behavior in Cairo's urban spaces of the more recent royal imports (julban) among them is a well-known, even notorious, problem of the Sultanate's fifteenth-century history. Through a combination of coercive action and anticipation of immediate material rewards, they were often a deciding factor in successions to the sultanate as well as the extent to which the reigns of sultans in this century were marked by the presence or absence of central stability and prosperity. ${ }^{34}$ In general, however, all of these developments aligned the identities, interests and conflicts of sultans, amirs and their personal entourages of family, followers and

Levanoni, "Rank-and-File Mamluks versus amirs". 
mamluks, in intimately centripetal ways with the political order that had given them their new lives of power, precedence and opportunity.

Unlike in previous centuries in Syro-Egypt, and unlike elsewhere in Islamic West-Asia, that political order of the fifteenth-century Sultanate of Cairo acquired a highly meritocratic, socially transcendent and increasingly ideational flavor. The reason for this is that, amidst the realities of Turko-Mongol tanistric politics, recurring attempts to again make it a dynastic order like in preceding centuries never succeeded. This is also illustrated in the short-lived case of al-Nasir Muhammad (r. 1496-98), son and successor of al-Ashraf Qaytbay (r. 1468-96), presented in Albrecht Fuess' discussion of this sultan's dynastic endeavors in Chapter 4 of this volume. In contrast, the expanding bureaucratic apparatus, the military and political experts who manned this apparatus, and the flows of human and financial resources that supported them, endured, even if only in tense and conflict-ridden ways. A remarkable factor that illustrates this non-dynastic trajectory of Syro-Egyptian state formation through the fifteenth century concerns the transformation of the position of sultan itself into a bureaucratic prize to be won, and lost, by the highest bidder. Such a qualification needs to be weighed against the achievements, longevity and subsequent empowering royalty of sultans such as al-Ashraf Barsbay (r. 1422-38), al-Zahir Jaqmaq (r. 1438-53), al-Ashraf Qaytbay (r. 1468-96) and Qanșawh (r. 1501-16). However, as mentioned before, in most cases, including those of the latter four sultans, the embattled accessions to the sultanate tended to crown long careers of military and court service and of resource accumulation in the royal shadows of peers. Apparently, it took a long time to acquire the main political and financial competences necessary for gathering (and keeping) the support of royal mamluks and amirs-courtiers. Many sultans in the fifteenth century had enjoyed long default careers in the state apparatus meaning that most of them only managed to accede to the sultanate at a fairly advanced age. Whereas Barsbay, in 1422, had been in his forties, his successor Jaqmaq was in his sixties when he succeeded to the throne in 1438. Al-Ashraf Inal (r. 1453-61), like his two predecessors, was originally a talented horseman and Circassian mamluk brought to Egypt from the Caucasus in the 139os. When he succeeded Jaqmaq, he was 73 and for him, this succession brought to a glorious close his long and eventful career of leadership as a military commander, as a governor in various Syrian towns and cities, and as an entrepreneurcourtier in Cairo. Similar stories of humble origins, service and empowerment have survived about most of Inal's successors, belonging to new, younger generations of mamluk state actors. Al-Zahir Khushqadam (r. 1461-7) and Qaytbay were in their fifties when they became sultan, and just like the unsuccessful septuagenarian al-Zahir Yalbay (r. 1467) and his equally unfortunate successor 
al-Zahir Timurbugha (r. 1467-68) they all had been brought to Egypt and Turkified in the 1420 s and 1430 sefore embarking upon long and conflict-ridden careers of military, administrative and court leadership. Finally, in the 149os a third generation of veteran military bureaucrats graduated into competent candidates for sultanic office, all originating as new mamluks in Egypt in the 1450 s and 146os, and including Qansawh, who was in his sixties when he ascended the throne in 1501 and who infamously died of a stroke in 1516 on a battlefield in Northern Syria, appalled by the victorious onslaught of the Ottoman sultan Selim. ${ }^{35}$

The absence of dynastic reproduction, and the regular competitive but coherent self-renewal of the Turko-Circassian political community more generally, seem unique for the 'Turkish' Sultanate's trajectory of state formation in fifteenth-century Islamic West-Asia. Nevertheless, the contemporaneous Ottoman Sultanate, which was obviously entirely constructed around the successful reproduction of the Ottoman dynasty, also experimented intensely with centripetal strategies of elite renewal that had a lot in common with those of the Southern Sultanate's. Here too, complete outsiders were transformed into central state actors through a system of total re-socialization and centralizing entanglement. In fact, upon closer inspection even the Ottoman dynasty itself was a product, and a telling illustration, of this gradual construction of a new, specifically Ottoman, political community. The sultans Murad (r. 1421-44, 1446-51), Mehmed (r. 1444-46, 1451-81) and Bayezid (r. 1481-1512) were all born from unfree women, selected and brought to the Ottoman court as royal concubines for the sole purpose of the royal lineage's successful reproduction. Only sultan Selim (r. 1512-20) was an exception to this rule, as the product of a marriage between Bayezid and the daughter of the Dulkadirid ruler of Elbistan in Southeast Anatolia. The latter, however, only represented an acute latefifteenth-century moment in the Sultanate's politics of distant integration, whereas the former cases were all part of a complementary, expanding practice of internal renewal and total integration. This was gradually generating a novel elite, even within the Ottoman royal household, gathering various sets of state actors whose competences and fortunes were intimately connected with the maintenance of the Ottoman dynastic order, and with the expansion of the apparatus that performed this order.

As Dimitri Kastritsis explains in great detail in Chapter 5 , when he writes about the doomed fate of the Çandarlı family of traditional Ottoman bureaucrats, this integrative reproduction of the Sultanate's political community 
through substantial renewal was anything but a straightforward and uncontested process. Like in the case of the Sultanate of Cairo the performance of this elite reproduction through the military and political prioritization of unfree dynastic agents (kapikulari) of varying expertise, gender and outsider origins was rooted in longstanding local and regional customs. Basically, the Ottoman solution to the perennial problem of the continuous need for loyal manpower appeared above all in the format of the so-called 'new army' (yeniçeri), a personal bodyguard entirely made up of trained footmen selected from the ranks of the sultan's unfree servants $(k u l)$. The precise historical trajectory of this Janissary corps, of similar central regiments of loyal and seasoned fighters, and of the kapikulari more in general, are forever lost in the mists of hindsight narratives explaining the origins and nature of Ottoman success. ${ }^{36}$ Whereas these phenomena had emerged and settled in already before the Sultanate's near destruction in the wake of Temür's victory in 1402, they only really started appearing as a dominant practice of Ottoman elite renewal in the mid-century reign of Mehmed II. At that time, they became more than ever a function of, and a contributing factor to, the Ottoman trajectory of state formation and of the expansion, specialization and symbiotic empowerment of the dynasty and its agents alike.

By the mid-fifteenth century at the latest, the Janissary corps of unfree footmen and similar central military regiments, all directly rewarded for their service by their master, the sultan, were not just providing regularly renewed Ottoman manpower. As kul whose destiny was directly dependent upon that of their master's, the sultan, they also balanced the power and interests of the Sultanate's traditional elites in important, centripetal ways. These included a wide range of military commanders, mostly belonging to ancient Turkish and Anatolian families of cavalrymen (sipahi) and spread all across the core Ottoman territories, as timar-holders with their own troops of horsemen, along separate hierarchies of power, status and resources. The substantial expansion of the Janissary corps under Mehmed, who managed to double its size to about 10,000 members by the 1470 , thus both represented and enabled a decisive shift in this traditional balance of military power to the sultan's benefit. As part of the Ottoman trajectory of state formation, however, this expansion also went hand in hand with the growth of the Janissaries' own political autonomy at the center of the Ottoman political order. With its ranks continuously being replenished from the $\mathrm{kul}$ and with its size steadily maintained at mid-century level, the Janissary corps acquired a reputation not just for causing havoc and turmoil at moments of political instability, but also for thus becoming a powerful actor

Kafadar, Between Two Worlds, pp. 112-113. 
at such moments, and one whose actions and choices left many marks on the Ottoman political order, without ever challenging that order. In the context of the tanistric succession struggles of the 1440 s, the 1480 s, and above all the 1500s, Janissary violence and anticipation of rewards proved a factor to be reckoned with, and their actions eventually even decided the accession of Selim (r. 1512-20) to the top of the Sultanate's political order. ${ }^{37}$

The kul's transformative role in the expansion and empowerment of the Ottoman state apparatus in the fifteenth century also played out at other, more individual, levels of elite participation and reproduction. In fact, the gradual diversification and specialization of the bureaucratic apparatus were also replicated within the burgeoning ranks of the sultan's unfree servants. Many of these $k u l$ came to be selected and trained for non-military duties, entering the service of the sultan's household and its expanding administration. In due course, particularly starting from the mid-century reign of Mehmed, several of these courtier-bureaucrats with kul origins even succeeded in becoming members of the sultan's leading advisory council, the imperial divan, or in obtaining the post of grand vizier, chairing the divan and acting as the most powerful Ottoman bureaucrat after the sultan. This remarkable wider employment and empowerment of individual $k u l$ at the sultan's court again provided for important centripetal checks and balances on the power and expertise of traditional Ottoman elites. This peculiar aspect of Ottoman bureaucratic growth and state formation gradually, often violently, and mostly haphazardly pushed these ancient Turkish and Anatolian families (including that of the Çandarlı) away from the center of Ottoman power. The Ottoman trajectory of state formation therefore eventually manifested itself in, and was indeed pursued by, the emergence of a very different, very Ottoman, political leadership. Consisting in increasingly exclusive ways of royal unfree or freed servants, this new political elite came to be dominated by regularly rejuvenated sets of military, administrative and court experts. These people were specifically selected and trained for the single purpose of service to a more and more abstract idea of Ottoman political order, and rose in the ranks of the expanding apparatus to positions of Ottoman authority and power through a combination of bureaucratic competence, royal favor and the elimination of competitors.

The expanding membership of the kapikulari thus gradually moved their field of action from serving in the sultan's personal entourage to having a significant impact within, and upon, the military, administrative and political apparatus of the Ottoman political order. This new Ottoman leadership of kul bureaucrats saw its ranks regularly replenished from particular sources of 
manpower that continued to ensure that all kul began their military or administrative careers more or less as newcomers to that political order. Many of the unfree who were selected to enter the sultan's palace for further specialist training and education did so as prisoners of war, captured during the endless military campaigns, especially against non-Muslim adversaries. Some also continued to enter via the commodity chains and specialist markets that connected the many corners of Islamic West-Asia in general with the wider world and that provided most of the power elites between Constantinople, Cairo and Samarkand with high-quality household and other staff. War and commerce were, however, expensive, resource-intensive and hazardous enterprises, and were not an easy way to provide for a steady supply of manpower to meet any growing demands. Unlike the 'Turkish' Sultanate in the Southwest the Ottoman leaderships managed to overcome this predicament and to complement the common but rather vulnerable dependence on production centers and commodity chains beyond a political center's direct reach and control. They turned to new, more internal, resources for elite renewal, and thus established more structured flows of manpower. In fact, in the Ottoman context this happened by tweaking - first on ad hoc bases but increasingly also along more regulated lines - particular tax farming and tributary arrangements with nonMuslim communities in a practical direction that could meet the continuous Ottoman need for manpower. These more specific arrangements became known as the Ottoman practice of 'collection' (devşirme). They entailed that from every forty households in Christian communities in regions such as Albania, Bulgaria, Serbia or Anatolia, one boy aged between 8 and 18 years was to be hand-picked as part of the payment of the Ottoman levy imposed on these communities and sent to the sultan's agents in Bursa, Edirne or Constantinople for allocation to the Janissary corps. If the boy was endowed with exceptional qualities he was sent to the palace and given several years' training for military or palace service, until he would be recruited to fill a vacancy in the corps or at the palace and start a career of bureaucratic service and, potentially, leadership in the expanding military, administrative or political apparatus of the Ottoman political order.

Whatever the violent, commercial or tributary arrangements that transformed these kul into unfree servants of the Ottoman sultan, they all obviously were entering the Ottoman household and, increasingly even becoming members of the Ottoman political community from backgrounds which were extremely diverse ethnically, socio-economically and culturally. Just like the Turkified mamluks in the Syro-Egyptian Sultanate, the aim of the preparation of these newcomers for Ottoman service was first and foremost to transform them into a more uniform community of loyal Muslim subjects of their master, 
the sultan. Albanians, Greeks and many others who were thus integrated into the center of power were all forced to convert to Islam. They had to learn to communicate in the Ottoman variant of the Turkic language, to conform to Ottoman Turkish values and rules of behavior, and to nurture social bonds with peers and with other Ottoman agents. In general, the idea was to make them 'Turkified' and allow them to become full partners and stakeholders in the dynasty's own, regularly replenished, elite social formation of the new 'Ottomans' (Osmanli). Metin Kunt summarizes as follows the early modern outcome of this process of the genesis of an entirely new Turko-Ottoman political community and identity:

By the mid-sixteenth century the Ottoman military-administrative elite was made up of these new Turkish-speaking Muslim officers who called themselves not Turkish but 'Roman' or 'Ottoman'; it was in this sense that Ottoman writers could comment that the 'Ottomans' took the best qualities of many nations and blended them to a new, superior race [...]. The Ottoman dynasty, too, was as much a product of this new blend as their servitors. From the beginnings of the family of Osman, the beys made marriage alliances with neighbouring Byzantine or Serbian princesses. Later the sultans chose not to continue such marriages but sired their sons and daughters with harem favourites of various ethnic backgrounds brought up in the palace. The language of the dynasty as well as of the polity remained Turkish, but not, strictly speaking, as a mother tongue. ${ }^{38}$

Half a century earlier, at the turn of the fifteenth century, the boundaries of the Ottoman political community were not yet so exclusively delineated by the kapikulari and their distinctive Turko-Ottoman identity. Nevertheless, as explained above, they certainly formed an increasingly formidable factor among the Sultanate's central power elites, as they and their expertise, action and relationships infiltrated, monopolized and reproduced the expanding tentacles of the Ottoman political order in (and beyond) the Northwestern corner of West-Asia. In this capacity they displayed many obvious parallels and connections with the contemporaneous hegemony of the Turko-Circassian community of mamluk bureaucrat-leaders in the Syro-Egyptian Sultanate. Even the social reproduction of these fifteenth-century mamluk bureaucrat-leaders and of their kul peers and contemporaries was largely bound by similar practices and conventions. The increasingly distinctive kapikulari status at this time remained the exclusive domain of kul of non-Muslim origins who owed their

38 Kunt, “Ottomans and Safavids", pp. 197-199 (quote p. 199). 
new lives, identities and careers entirely to their master, the sultan. For this reason, until at least the 1510 s the many members of the Janissary corps were even prohibited from marrying and producing offspring. As the chains of authority and command were lengthening in the course of the Sultanate's process of state formation, selection for, access to, and management of the kapikulari was also increasingly administered and controlled by kul bureaucrats rather than by the sultan himself or any other courtier of more traditional stock. There was thus a growing, self-fulfilling bias at the Ottoman center in relation to the expanding ranks, expertise and relationships of the kul, even regarding the management of their own renewal. This meant that bureaucratic power amassed by an Ottoman military or court leader was increasingly only transmitted on the basis of bureaucratic competence, favor and patronage, and success in the endless competition with peers and others, and not on the basis of kinship or lineage.

Several of the long careers in Turkifying palace service, bureaucratic specialization and, eventually, Ottoman leadership and authority during the long reigns of sultans Mehmed and Bayezid represent a strong illustration of, and defining factor in, the Ottoman trajectory of state formation and of the mutual empowerment of the kapikulari and of their master, the sultan. These careers also demonstrate how the politics whereby the central elite was reproduced by substantial renewal from within the Sultanate's territorial boundaries enabled different kinds of remarkable continuity that intersected in successful ways with the politics of Ottoman integration. Out of the fifteen different individuals who occupied the court's leading position of grand vizier between the $1450 \mathrm{~s}$ and the 1510 s only three belonged to traditional Turkish families. All the other grand viziers in this period had Christian backgrounds, just like many other viziers, lower officials and commanders. They entered the Ottoman political order and embarked upon new, Ottoman, careers of authority and power as hand-picked devşirme levies mostly collected from rural communities in the Balkans or as prisoners-of-war captured in the ongoing confrontations with (former) Byzantine and Balkan elites. These various coercive arrangements thus simultaneously allowed some of the experts, expertise and relationships of power of its former Christian adversaries to be directly integrated into the center of Ottoman power. This was one distinctive outcome of the unique situation of the Ottoman Sultanate's substantial expansion into the Christian Balkans, and this remarkable phenomenon again empowered both the Sultan, providing him with a particular group of new loyal servants, and these new kul, including many of former Byzanto-Balkan noble stock who were now converted to Islam and Turkified. At the turn of the fifteenth to sixteenth centuries many of the latter became leading members of the increasingly powerful 
Turko-Ottoman political community and of the political order to which that community owed its very existence. ${ }^{39}$ Very symbolically, and tellingly, they even had in their ranks at least two nephews of the last Byzantine emperor. Captured as young boys during the Ottoman conquest of Constantinople in 1453, they were only known by their Muslim names and Turko-Ottoman titles as Mesih Pasha (d. 1501) and Has Murad Pasha (d. 1473). These boys eventually came to hold major positions of military and palace leadership, including the governorship of the Balkans (beylerbey of Rumeli) and the grand vizierate during the reigns of sultans Mehmed and Bayezid. They both seem to have done so without ever losing at least some appreciation for their imperial Byzantine origins. ${ }^{40}$ Inspired by these and many similar cases from the latter half of the fifteenth century Karen Barkey, paraphrasing Heath Lowry, concludes with good reason that "after 1453, the Ottoman palace was packed with 'Byzantine and Balkan aristocrats turned Vezirs". ${ }^{41}$

\subsection{The Politics of Central Elite Reproduction: Scholars, Scribes and Tajiks}

This remarkable transformation-cum-integration of the Ottoman Sultanate's political community through an ever more internalized and automated process of renewal was quite unique for fifteenth-century West-Asia. This singularity manifested itself especially in this process' successful marginalization of traditional Turkish and Anatolian elites and their more centrifugal interests, and also in the way it converged various local experts, expertise and relationships of power in the sultan's expanding household, palace and political order. Elsewhere, reproduction of power and status among central elites happened in more diverse and multivalent ways, which require a separate discussion.

In the Sultanate of Cairo, the regular renewal of military-bureaucratic elites certainly paralleled that of the 'Ottomans' as a self-sustaining and centripetal practice. In the Sultanate's case this determined the marginalization of dynastic trends even more, including in relation to access to the very top of its political order. At the same time, however, the Sultanate followed an entirely different path from that of the remarkable convergence of the Ottoman state formation trajectory in the kapikulari. In the latter Ottoman case the traditional bureaucratic distinctions between 'the men of the swords', 'the men of the

39 Lowry, The Early Ottoman state, pp. 115-130 ("Chapter Seven: The Last Phase of Ottoman Syncretism - the subsumption of members of the Byzanto-Balkan aristocracy into the Ottoman ruling elite").

40 Lowry, "A Note on three Palaiologon princes as members of the Ottoman ruling elite".

41 Barkey, Empire of Difference, p. 80; Lowry, The early Ottoman State, p. 118. 
pen' and 'the men of the turbans' certainly continued to inform the organization of the expanding state apparatus. However, the boundaries of the first two categories appeared as increasingly fluid in terms of people and relationships of power, especially in the wake of the expanding involvement and diversification of the Ottoman sultan's kul. In the Sultanate of Cairo, however, a more complex politics of central elite reproduction appears to have existed. This complemented, in equally centripetal ways, the construction of a TurkoCircassian political community. Unlike in the Ottoman case, in Cairo and elsewhere in the Sultanate those traditional boundaries of specialization and reproduction were constructed along alternative lines of functional and social distinction. There, mamluks generally—but not exclusively—held titles, positions, privileges and responsibilities of the first, military category while a mix of experts particularly with local Syro-Egyptian origins continued to manipulate the mechanisms of central taxation, remuneration, communication and justice that are traditionally ascribed to the second and third categories.

In fact, in fifteenth-century Cairo several of the latter experts became extremely wealthy bureaucratic leaders in their own right, controlling the court's flows of resources, its symbolic apparatus and related sets of court relationships in highly empowering ways. Most of these non-military competitors for power at the top of the Sultanate's political order actually came from a mere handful of families of administrators and scholars of (formerly) Christian or Muslim, and Syrian or Egyptian origins. After many years of engagement in local low-profile scholarship and scribal service, different members of these families had only entered Cairo's court and its expanding bureaucratic apparatus in the 1410 s and 1420s, as a function of their employment in the pre-sultanic, amiral households of the sultans al-Mu'ayyad Shaykh (r. 1412-21) and al-Ashraf Barsbay (r. 1422-38). Men (and women) from the most successful of these new bureaucratic elite families, such as the Banu al-Barizi from Hama, the Banu Muzhir from Damascus, and the Egyptian Coptic converts of the Banu Katib Jakam, continued to appear at court until the end of the Sultanate a century later. There, they would partake in the performance of its administrative, religious and sometimes even military apparatus, currying royal favor, gathering enormous wealth, and pursuing all kinds of relationships of power and expertise, including through royal, amiral and other highly political marriages. Dynastic tendencies therefore certainly determined the transmission of office and power within many of these families. Examples here include the Banu Katib Jakam, whose members held the top post of the supervision of the royal fisc (nazr al-khass) continuously between 1425 and 1458 and that of the army bureau (nazr al-jaysh) between 1466 and 1496, or the formerly Coptic Banu 
l-Jian family, whose members were associated with the supervision of the treasury (nazr al-khizana) for about a century until $1501 .{ }^{42}$

Nevertheless, despite this apparent trend towards dynastic reproduction, a more centralizing practice of competitive renewal simultaneously imposed itself. This practice was defined by factors of competence, favor, resources and their opposites, rather than simply by any rights or privileges of kinship or lineage. Such qualities and competences were obviously rooted in particular, administrative skills and successes, which created opportunities and opened many doors, and which were certainly easier to possess or acquire for these and many similar families' offspring than for any outsider. At the same time, however, just as with the Turko-Circassian community of royal mamluks and amirs, the acquisition of authority and leadership in the expanding state apparatus was a different matter from bureaucratic service. That acquisition instead had more to do with more generic qualities of entrepreneurship, charisma, distinction, brokerage and wealth. The ongoing growth of the Sultanate's apparatus therefore continuously created new opportunities for ambitious inand outsiders, as well as providing all kinds of new arenas of fierce competition along the Sultanate's lengthening chains of authority and agency. As a result, at the pinnacle of the Sultanate's fifteenth century political order, sometimes not just families, but also individuals of lesser and diverse professional and social origins - such as the infamous Abu l-Khayr al-Naḥhas ('the Coppersmith') (1412-59) - occasionally emerged as new bureaucratic leaders. When this happened, it was often much to the dismay and horror of their competitors of more traditional stock, and with important mitigating effects on the reproduction of power for any more consolidated group of administrators at court. ${ }^{43}$

Even among scholars and scribes, therefore, hierarchies of central leadership were not easily reproduced, but rather continuously challenged and renewed in often conflict-ridden ways. Participation and advancement in these hierarchies depended on bureaucratic skills and precedents, but it was even more contingent on an individual's political and financial competences which they required for gathering (and keeping) the support of subordinates, peers and sovereigns. As a result, like the careers of sultans and amirs, those of some of the most prominent non-military leaders and courtiers of the Sultanate's

42 Martel-Thoumian, Les civils et l'administration dans l'état militaire mamlük (IXe/XVe siècle).

43 Mortel, "The Decline of Mamlūk Civil Bureaucracy in the Fifteenth Century"; Elbendary, Crowds and Sultans. 
fifteenth century history were also marked by many years of service and of accumulating political and financial resources-relationships, wealth and power. We might think of figures such as Jamal al-Din Yusuf b. Katib Jakam (1416-58), supervisor of the royal fisc (nazir al-khass) for five successive sultans (1437-58), Yahya al-Ashqar (d. 1469), major-domo (ustadar) for most of the period between 1440 and 1467, and Abu Bakr b. Muzhir (1428-88), the court's confidential secretary (katib al-sirr) at the head of the royal chancery from 1463 until his death in 1488. At the same time, however, in the absence of any real dynastic practices, the political opportunities and autonomy thus acquired by these and many more central bureaucrat-scholars and -scribes in the fifteenthcentury Syro-Egyptian Sultanate remained highly conditional and volatile. Above all, they remained intimately connected to the bureaucratic roles that they managed to play, to the political and financial resources that those roles enabled them to tap into, and even to the conflicts over those roles and resources in which they continuously had to engage. Their career paths of service and leadership therefore continued to be tied up in centripetal ways with the maintenance and reproduction of the political order to which they mostly owed those careers. This was true even when on an individual or collective basis they were bound to prioritize their own rather than that order's empowerment. ${ }^{44}$ The powerful leadership of many of these local bureaucrats, and the regular competitive renewal of their ranks, therefore remained an illustration, and function, of the Sultanate's particular, mutually empowering, trajectory of state formation, just like that was also true for its Turko-Circassian political community of amirs and sultans.

As mentioned above, unlike their Turko-Circassian and Turko-Ottoman counterparts the Timurid and Turkmen politico-military communities in the North and East remained much more fragmented and determined by the tanistric political and economic interests of 'Turkish' military leaders, families and lineages. These mostly owed their continued regional empowerment to Temür's construction of a new elite at the turn of the fourteenth century, and to its largely successful dynastic reproduction throughout the fifteenth century. At the same time, however, the highly contested trajectories of state formation that marked the reigns of Shah Rukh, Abu Sacid, Jahan Shah, Uzun Hasan and Sultan Husayn did not just continue to have to engage in mutually restrictive ways with these 'Turkish' elites and the reproduction of their mainly centrifugal interests. These trajectories certainly also interacted closely with the reproduction of particular Persian scribal and scholarly elites and their practices and skills, both benefiting from this reproductive process and stimulating it in

Miura, "Administrative Networks in the Mamluk Period". 
centripetal and political ways that remind one of the experiences of their peers in the Sultanate of Cairo. These elites were collectively identified as 'Tajiks' and employed as expert administrators managing the assets and interests of both 'Turkish' amirs and Timurid-Turkmen rulers across the region. Throughout the fifteenth century several individual members of these elites emerged from administrative service in these rulers' households and palaces to bureaucratic leadership in their political orders. They were deeply involved, in mutually empowering ways, in the expansion, maintenance and reproduction of those orders, refining and controlling most of their mechanisms of central taxation, remuneration, communication and justice. In the process, these administrators accumulated substantial political and financial resources alongside relationships, wealth and power, from which their own families, friends and followers equally benefited.

As Beatrice Manz also explains in detail in her chapter on the political involvement of Iranian landed elites in Part 3 of this volume, quite a few such 'Tajik' leaders of Perso-Iranian origins thus became formidable political leaders in their own right, occasionally even engaging in military leadership and warfare with their own, personal troops. In these ways they managed to counter in significant and effective centripetal ways 'Turkish' competitors for central power and 'Turkish' challengers of that power and its political order. Among the most remarkable and powerful of these non-military leaders at the Timurid and Turkmen courts were undoubtedly Ghiyath al-Din Pir-Ahmad Khwafi (d. 1453), head of Shah Rukh's finance office between 1417 and 1447 who later served at the courts of various other Timurid princes, and his son Majd al-Din Muhammad Khwafi, chief accountant at Sultan-Husayn's court since its first installation in Herat in 1469, who was chief agent of the court's centralizing trajectory of bureaucratic expansion and specialization. Eventually, in 1494, after many years of competition and confrontations with the court's 'Turkish' memberships, Majd al-Din Muhammad was tortured, deprived of his allegedly fabulous wealth, and murdered. ${ }^{45}$ These two careers, spanning almost a century of Timurid rulership in West-Asia's East, represent a remarkable, personalized connection between these two distinct moments of Timurid state formation during the first half and final quarter of the fifteenth century respectively. In fact, connections such as these are anything but exceptional for political careers in the Timurid and Turkmen North and East, where the imperfect integration of 'Turkish' commanders and the balancing empowerment of 'Tajik' administrative experts represented practical realities that connected individuals, groups and institutions across all kinds of regularly shifting boundaries of loyalty, service and political 
order. $^{46}$ The careers of Pir-Ahmad and his son Muhammad at various Timurid courts are therefore a powerful illustration of how in Islamic West-Asia's North and East state formation also appeared as one, regularly reproduced, process of political transformation, albeit along its own, distinctive trajectory of symbiosis and confrontation between fifteenth-century 'Turkish' and 'Tajik' political communities, and of the latter's reproduction and empowerment across Timurid and Turkmen (and occasionally also Ottoman) leaderships.

\section{Epilogue: The Trajectories of Fifteenth-Century Boundaries and Ideals}

It is well known that of these many distinct trajectories of Turko-Mongol state formation in Islamic West-Asia, the Ottoman was the only one that continued more or less unaltered, indeed in increasingly coherent ways, into the sixteenth century. Key factors in this process undoubtedly included military and administrative expansion, personal and institutional longevity, internalized elite renewal and the reproduction of the Ottoman Sultanate as an increasingly autonomous, integrative and empowering bureaucratic order. But another defining factor was certainly also the strength and tenacity of the era's other trajectories of state formation in the Southwest, North and East of West-Asia. For the Cairo Sultanate this manifested itself from the late 1510 s onwards in the rapid local integration of Syro-Egyptian elites and practices into this Ottoman process, in the continuation of much of the Sultanate's political apparatus, now adapted to Ottoman political realities, and in the substantial recalibration of the latter realities to equally accommodate the definitive shift of the Ottoman political order towards the very center of the Muslim and Eurasian worlds. The latter shift, however, was a function not just of Ottoman expansion and appropriation of the Cairo Sultanate's apparatus and elites, but also of the particular continuation of the more ambiguous Timurid-Turkmen state formation route in Islamic West-Asia's East, in Uzbek Transoxiana and Mughal Northern India as well as in Safavid Iran. Making its appearance on the West-Asian stage at the turn of the new century, Shah Ismail's (r. 1501-24) Safavid authority was personally, practically and institutionally in many ways one of the main heirs to this Timurid-Turkmen trajectory. At the same time, when that authority acquired a more coherent appearance in the course of the sixteenth century, this contributed to the emergence of new East-West frontiers that were also strongly

46 Woods, The Aqquyunlu, pp. 106-110. 
tied to the formation of the political, social and cultural order of the Safavids' early modern Ottoman counterpart.

That early modern Ottoman social order was actually described by Malcolm Yapp as "compartmentalized", and as

a block of flats in which the inhabitants only met in the corridors [...] [and in which] each compartment had its hierarchy and the leaders of those hierarchies transacted much business together [...] [I]t was the people who bridged the compartments, qädīs and notables, who made the system work. ${ }^{47}$

This view certainly reminds one of above-mentioned statements about the segmented nature of Turko-Mongol politics and socio-economic organization in fifteenth-century Islamic West-Asia. However, although the block of flats, with clearly defined compartments, corridors and inhabitants with clearly defined roles is attractive, it is not the most apt metaphor here, given the ongoing dynamics of expansion, fragmentation and circulation, recurrent attempts at political stabilization and administrative penetration, and, more generally, different trajectories of Turko-Mongol state formation. Even in the Ottoman North-West those dynamics, attempts and trajectories remained insufficiently fixed, structured or coherent to justify thinking of them in terms of clearly defined and delineated blocks, flats, compartments, corridors and roles. Nevertheless, some social phenomena in the foregoing survey may certainly be understood as multivalent compartments, autonomous corridor trafficking and multiple roles and hierarchies, even if they did appear only in very temporary, localized, premature or ad hoc formats, and in conditions of continuous negotiation, accommodation, contestation and experimentation. The metaphor therefore may still have some value, as it makes clear how old and new compartments continued to take shape and interact amidst the fluidity, volatility and incongruence of fifteenth-century West-Asian social order At this time the skeleton of certain blocks of flats even became visible, although their construction remained very much creative work in progress, and although the more coherent early modern appearances of some of that work were all but predetermined. Above all, this imperfect yet insightful metaphor certainly helps one to remain aware of the impact of Turko-Mongol trajectories of state formation on these constructions of social order, not least also reminding us of the limits of that impact. Driven by coercive power and integrative ambitions these trajectories generated a productive centrality for rulers, elites and political 
communities in those skeletons. At the same time, these trajectories emerged almost incidentally, and with differing rates of success, from multivalent actions that were above all about creating new compartments, about expanding, reorganizing and repositioning them, and about pursuing priority in the constantly changing corridors of compartmental relationships, rather than attempting to construct an entire block, monopolizing it and making "the system work".

Yapp also suggested that due to the "compartmentalized nature" of early modern Ottoman social order, "the Muslim ideal of a stable society, based on justice and composed of the four classical pillars - bureaucrats, soldiers, merchants and artisans, and peasants-bore little relation to [...] reality $[\ldots]^{\prime \prime}{ }^{48}$ Considering the differences between the "compartmentalized nature" of the early modern Ottoman order and that of fifteenth-century Islamic West-Asia, the latter fifteenth-century reality was even farther removed from that ancient ideal of one stable and just society. Nevertheless, the ideal was also very present across that reality's unstable political landscape, perhaps even more actively than generally tends to be acknowledged. It informed widespread ideas about good rulership and legitimate socio-political order. ${ }^{49}$ It permeated the aforementioned multiple pursuits to organize relationships of coercion and power along the labels of 'the men of the sword, the men of the pen and the men of the turbans' and through legislation and legal action. It finally also guided many dichotomous explanations of the era's fluid and volatile roles and hierarchies, such as the binaries of 'Turks' and 'Tajiks', 'Persians' and 'Arabs', 'elites' (khassa) and 'commoners' ('amma), tax payers and tax recipients, commanders and administrators, or Muslims and Christians. These and many similar ideas, labels, actions, binaries and explanations contributed to the many appearances of social order across West-Asia, amidst those complex realities of segmentation, fragmentation and competitive empowerment. Above all, they operated everywhere as highly fluid specimens of socio-cultural boundaries that were constantly crossed, challenged and reconfigured. In fact, the formulation of such boundaries with the aid of these and related ideas and explanations continued to represent important stakes in the endless negotiation, accommodation, contestation and experimentation from which both compartments and corridors emerged, stimulating communication across such compartmentalization and contributing to the appearance of larger skeletons and contours of order.

48 Yapp, The Making of the Modern Near East, p. 9.

49 Darling, A History of Social Justice and Political Power in the Middle East, esp. pp. 113-118 ('Post-Mongol Polities (1335-1506)'). 
These fluid socio-cultural boundaries, and these ideas and ideals more in general, were always also highly political, constructing, and constructed by, all kinds of relationships of power across Islamic West-Asia. As such they were always also part of the ideologies of Turko-Mongol rule in fifteenth-century West-Asia, and of wider apparatuses of political communication and performance. Despite their importance for fifteenth-century West-Asia's diverse trajectories of state formation, these symbolic apparatuses have not been dealt with separately in this chapter. This is partly because that would go beyond the more socio-politically oriented focus of the current volume, but also because much pioneering work still remains to be done in this highly complex and intellectually sophisticated, but traditionally downgraded and even oftneglected, domain. ${ }^{50}$ Today these ideologies and discourses of power, and the highly intricate trans-regional webs of meaning-making and knowledge practices to which they pertain, are arguably even less well-known, studied and understood, in the more general entangled context of fifteenth-century TurkoMongol state formation in particular, than Islamic West-Asia's power elites, its institutions and practices, and its socio-political transformations. Recent years have certainly seen a growing acknowledgement of the need for research into this field. Scholars are beginning to realize the potential value in investigating the nature and wide-ranging impact of the often very novel sets of ideas and ideals of legitimate rule and kingship that came to dominate West-Asian discourses of power with and after Temür. There is also a growing acknowledgement of the riches of this subject, and of the experimental creativity and the shared mix of memories, symbolic practices and cultural systems by which Turko-Mongol leaderships, Arabo-Persian courtiers and Muslim intellectuals of wide-ranging expertise and mobility engaged in legitimizing, explaining and disciplining the eclectic, violent and volatile political realities of the era. Models of leadership in West-Asia in the fifteenth century operationalized eclectic imaginations of social justice, divine favor, dynastic precedence, ideal rule, royal wisdom, millenarian sovereignty, charismatic sanctity and their like.

5o See especially Watt, Islamic Political Thought and Crone, Medieval Islamic Political Thought. Despite the comprehensiveness suggested by these titles, these two authors generally prefer to neglect any detailed discussion of the later medieval period, due to their focus on the imamate. This was a religio-legal concept of Islamic sovereignty that appeared in the fifteenth century with substantially altered meanings that are difficult to comprehend from Watt's and Crone's strictly Arabo-Islamic genealogical perspective. See also Antony Black, The History of Islamic Political Thought (who tellingly decided to entitle his brief survey of important fifteenth-century thinkers such as Jalāl al-Dīn Muhammad Davānī and Faẓl Allāh Khunjī-Iṣfahānī “The Decline of Classical Islamic Political Thought" [pp. 183-188]). 
These highly creative symbolic apparatuses enabled very intense connections between the different courts of the era and their communicative systems, and also with their Perso-Islamic, Turko-Saljuq and Mongol-Chinggisid antecedents as well as with the ways their imperial successors made their impressive appearances on the early-modern Eurasian stage. ${ }^{51}$ It remains a daunting task to untangle the genealogies, the communications and performances, and the functions and agents of these eclectic imaginations, which are to be situated within the fields of theology, philosophy, mysticism, occultism, mathematics, historiography and various other premodern Eurasian knowledge traditions. At the same time, pursuing this is highly desirable, not least because as demonstrated above almost all of the, mostly narrative, extant sources for those trajectories of fifteenth-century state formation are in many ways products, and constituents, of those symbolic apparatuses. Even though it is a task that cannot be addressed in the current context, this certainly remains a highly relevant and very promising one that calls for further, preferably collaborative, initiatives along similar lines of West-Asian, and for that matter Eurasian, entangled research.

\section{Bibliography}

Abu Ghazi, 'Imad Badr al-Din, Tatawwur al-Hiyāza al-Zirāiña zaman al-Mamālìk alJarākisa: dirāsa fì bay' amlāk bayt al-māl (Giza: 'Ein for Human and Social Studies, 2000).

Adriaenssen, Veerle \& Jo Van Steenbergen, "Mamluk authorities and Anatolian realities: Jānibak al-Ṣūî̀, sultan al-Ashraf Barsbāy, and the story of a social network in the Mamluk/Anatolian frontier zone, 1435-1438",Journal of the Royal Asiatic Society 28/4 (2016): 591-630.

Amīn, Muḥammad M., Al-Awqā wa-l-Hayā al-Ijtimāà̃a fí Mișr, 648-923 A.H./1250-1517 A.D. (Cairo: Dār al-Nahḍa al-'Arabīya, 1980).

Apellániz Ruiz de Galarreta, Francisco J., Pouvoir et finance en méditerranée prémoderne: le deuxième état mamelouket le commerce des épices (1382-1517) (Barcelona: Consejo Superior de Investigaciones Cientificas, 2009).

51 See especially Woods, The Aqquyunlu, pp. 100-120; Manz, Power, Politics and Religion, pp. 178-244; Bashir, Messianic Hopes, pp. 31-41 ('The Making of a Messianic Age in Tīmūrid Iran and Central Asia'); Moin, The Millennial Sovereign, pp. 23-55 ('The Lord of Conjunction: Sacrality and Sovereignty in the Age of Timur'); Murphey, Exploring Ottoman Sovereignty; Lingwood, Politics, Poetry, and Sufism; Van Steenbergen, Caliphate and Kingship, pp. 90-104; Melvin-Koushki, "Early Modern Islamicate Empire: New Forms of Religiopolitical Legitimacy”; Markiewicz, The Crisis of Kingship in Late Medieval Islam. 
Ayalon, David, "Baḥrī Mamlūks, Burjī Mamlūks-Inadequate Names for the Two Reigns of the Mamlūk Sultanate", Tärīh 1 (1990): 3-53.

Barkey, Karen, Empire of Difference: the Ottomans in comparative perspective (Cambridge: Cambridge University Press, 2008).

Barthold, Vladimir V, Four Studies on the History of Central Asia. 2: Ulugh-beg, V. Minorsky, transl. (Leiden: Brill, 1958).

Bashir, Shahzad, Messianic Hopes and Mystical Visions: the Nürbakhshīya between Medieval and Modern Islam (Columbia: University of South Carolina Press, 2003).

Binbaş, İ. Evrim, "Did the Hurufis Mint Coins? Articulation of Sacral Kingship in an Aqquyunlu Coin Hoard from Erzincan", in A.C.S. Peacock and S.N. Yıldız, eds., Islamic Literature and Intellectual Life in Fourteenth- and Fifteenth-Century Anatolia (Istanbuler Texte und Studien vol. 34) (Würzburg: Erlon Verlag Würzburg, OrientInstitut Istanbul, 2016), pp. 137-170.

Binbaş, İ. Evrim, Intellectual Networks in Timurid Iran. Sharaf al-Dìn 'Alī Yazdī and the Islamicate Republic of Letters (Cambridge: Cambridge University Press, 2016).

Black, Antony, The History of Islamic Political Thought. From the Prophet to the Present (Edinburgh: Edinburgh University Press, 2001).

Burak, Guy, "The Second Formation of Islamic Law: The Post-Mongol Context of the Ottoman Adoption of a School of Law", Comparative Studies of Society and History 55 (2013):579-602.

Coulon, Damien, Barcelone et le grand commerce d'Orient au Moyen Âge: un siècle de relations avec l'Egypte et la Syrie-Palestine (ca. 1330-ca. 1430) (Madrid \& Barcelona: Casa de Velázques \& Institut Europeu de la Mediterrània, 2004).

Crone, Patricia, Medieval Islamic Political Thought (Edinburgh: Edinburgh University Press, 2005).

Crossley, Pamela K., “Military Patronage and Hodgson's Genealogy of State Centralization in Early Modern Eurasia", in E. Burke and R.J. Mankin, eds., Islam and World History. The Ventures of Marshall Hodgson (Chicago: University of Chicago Press, 2018), pp. 102-114.

Darling, Linda T., A History of Social Justice and Political Power in the Middle East: The Circle of Justice from Mesopotamia to Globalisation (New York: Routledge, 2013).

Dickson, Martin B., "Uzbek Dynastic Theory in the Sixteenth Century", In Proceedings of the 25th International Congress of Orientalists. 4 vols. (Moscow, 1963). 3:208-216.

Elbendary, Amina, Crowds and Sultans. Urban Protest in Late Medieval Egypt and Syria (Cairo: American University in Cairo Press, 2015).

Fleet, Kate, European and Islamic Trade in the Early Ottoman State: the Merchants of Genoa and Turkey (Cambridge: Cambridge University Press, 1999, repr. 2006).

Fletcher, Joseph F., "Turco-Mongolian Monarchic Tradition in the Ottoman Empire", Harvard Ukranian Studies 3/4 (1979-1980): 236-252. 
Garcin, Jean-Claude, "Note sur les rapports entre bédouins et fallahs à l'époque mamluke", Annales islamologiques/Hawlīyāt islāmōya 14 (1978): 147-163.

Har-El, Shai, Struggle for Domination in the Middle East: the Ottoman-Mamluk War, 1485-91 (Leiden: Brill, 1995).

Imber, Colin, The Ottoman Empire, 1300-1650. The Structure of Power (New York: Palgrave, 2002).

Igarashi, Daisuke, Land Tenure and Mamluk Waqfs (Ulrich Haarmann Memorial Lecture vol. 7) (Bonn: EB Verlag, 2014).

Inalcik, Halil, "Bursa and the Commerce of the Levant", Journal of the Economic and Social History of the Orient 3/2 (1960): 131-147.

Inalcik, Halil, "Harīr. ii-The Ottoman Empire", Encyclopaedia of Islam. Second Edition (Leiden: Brill, 1960-2012).

Inalcik, Halil, An Economic and Social History of the Ottoman Empire. Volume one. 13001600 (Cambridge: Cambridge UP, 1994).

Inalcik, Halil, "Autonomous Enclaves in Islamic States: Temlîks, Soyurghals, YurdluḳOcaḳlıks, Mâlikâne-Mukāța 'as and Awqāf', in J. Pfeiffer and Sh.A. Quinn, eds., History and Historiography of Post-Mongol Central Asia and the Middle East. Studies in Honor of John E. Woods (Wiesbaden: Harassowitz Verlag, 2006), pp. 112-134.

Kafadar, Cemal, Between Two Worlds: the Construction of the Ottoman state (Berkeley: University of California Press, 1996).

Kunt, Metin, "Ottomans and Safavids. States, Statecraft, and Societies, 1500-1800", in Y.M. Choueiri, ed., A Companion to the History of the Middle East (Chichester: Blackwell, 2002), pp. 191-205.

Lantschner, Patrick, "Fragmented Cities in the Later Middle Ages: Italy and the Near East Compared", English Historical Review 130/544 (June 2015): 546-582.

Levanoni, Amalia, "Rank-and-File Mamluks versus Amirs: new norms in the Mamluk military institution", in U. Haarmann and Th. Philipp, eds., The Mamluks in Egyptian Politics and Society (Cambridge: Cambridge University Press, 1998), pp. 17-31.

Levanoni, Amalia, "The Sultan's Laqab - a sign of a new order in Mamluk Factionalism?", in M. Winter and A. Levanoni, eds., The Mamluks in Egyptian and Syrian Politics and Society (The Medieval Mediterranean: Peoples, Economies and Cultures, 400-1500 vol. 51) (Leiden: Brill \& Boston, 2004), pp. 79-115.

Lingwood, Chad G., Politics, Poetry, and Sufism in Medieval Iran. New perspectives on Jami's Salaman va Absal (Studies in Persian Cultural History vol. 5) (Leiden: Brill, 2014).

Loiseau, Julien, "De l'Asie centrale à l'Égypte: le siècle turc", in P. Boucheron, J. Loiseau \& Y. Potin, eds., Histoire du Monde au XV siècle (Paris: Librairie Arthème Fayard, 2009), pp. 34-49.

Lowry, Heath W., The Nature of the Early Ottoman state (Albany: State University of New York Press, 2003). 
Lowry, Heath W., "A Note on three Palaiologon princes as members of the Ottoman ruling elite", in H. Lowry, Defterology revisited: studies on 15th and 16th century Ottoman society (Analecta Isisiana 101) (Istanbul: Isis, 2008).

Manz, Beatrice F., The Rise and Rule of Tamerlane (Cambridge: Cambridge University Press, 1999).

Manz, Beatrice F., Power, Politics and Religion in Timurid Iran (Cambridge: Cambridge University Press, 2007).

Markiewicz, Christopher, The Crisis of Kingship in Late Medieval Islam. Persian Emigres and the Making of Ottoman Sovereignty (Cambridge: Cambridge University Press, 2019).

Martel-Thoumian, Bernadette, Les civils et l'administration dans l'état militaire mamlūk (IX $X^{e} X V^{e}$ siècle) (Damas: Institut français de Damas, 1992).

McChesney, Robert D., Waqf in Central Asia: Four Hundred Years in the History of a Muslim Shrine, 1480-1889 (Princeton: Princeton University Press, 1991).

Melvin-Koushki, Matthew, "Early Modern Islamicate Empire: New Forms of Religiopolitical Legitimacy", in A. Salvatore, R. Tottoli and B. Rahimi, eds., The Wiley Blackwell History of Islam (Oxford: Wiley Blackwell, 2018), pp. 353-375.

Miura, Toru, "Administrative Networks in the Mamluk Period: Taxation, Legal Execution, and Bribery", in T. Sato, ed., Islamic Urbanization in Human History: Political Power and Social Networks (London and New York: Kegan Paul International, 1997), pp. 39-76.

Moin, A. Azfar, The Millennial Sovereign: Sacred Kingship and Sainthood in Islam (New York: Columbia University Press, 2012).

Mortel, Richard T., "The Decline of Mamlūk Civil Bureaucracy in the Fifteenth Century: the Career of Abū l-Khayr al-Naḥhās", Journal of Islamic Studies 6 (1995): 173-188.

Murphey, Rhoads, Exploring Ottoman Sovereignty: tradition, image and practice in the Ottoman imperial household, 1400-180o (London: Continuum, 2008).

Murphey, Rhoads, "The Ottoman Economy in the early imperial age", in Christine Woodhead, ed., The Ottoman World (London \& New York: Routledge, 2011, 2013), pp. 28-30.

Meloy, John L., Imperial Power and Maritime Trade: Mecca and Cairo in the later Middle Ages (Chicago: Middle East Documentation Center, 2010).

Petry, Carl F., "Fractionalized Estates in a Centralized Regime: The Holdings of alAshraf Qāytbāy and Qānșūh al-Ghawrī according to their Waqf Deeds", Journal of the Economic and Social History of the Orient 41/1 (1998): 96-117.

Popper, William, Egypt and Syria under the Circassian Sultans. 1382-1468 A.D. Systematic Notes to Ibn Taghrî Birdîs Chronicles of Egypt. Part two: Government (Berkeley \& Los Angeles: University of California Press, 1955). 
Rapoport, Yossef, "Royal Justice and Religious Law: Siyāsah and Shari'ah under the Mamluks", Mamlūk Studies Review 16 (2012): 71-102.

Sabra, Adam, "The Rise of a New Class? Land Tenure in Fifteenth-Century Egypt: a review article", Mamlūk Studies Review 8/2 (2004): 203-210.

Subtelny, Maria E., Timurids in Transition. Turko-Persian Politics and Acculturation in Medieval Iran (Leiden \& Boston: Brill, 2007).

Tilly, Charles, "War Making and State Making as Organized Crime", in P. Evans, D. Rueschemeyer \& Th. Skocpol, eds. (Cambridge: Cambridge University Press, 1985), pp. $169-187$.

Tilly, Charles, Coercion, Capital, and European States, AD 990-199o (Cambridge (Mass.): Blackwell, 1994).

Vallet, Eric, L'Arabie marchande. État et commerce sous les sultans rasûlides du Yémen (626-858/1229-1454) (Paris: Publications de la Sorbonne, 2010).

Van Steenbergen, Jo, "Nomen est Omen. David Ayalon, the Mamluk Sultanate, and the Rule of the Turks" (2013, pre-publication author version at https://www.academia .edu/4510845).

Van Steenbergen, Jo, "Caught between Heredity and Merit: Qūṣun (d. 1342) and the legacy of al-Nāṣir Muḥammad b. Qalāwūn (d. 1341)”, Bulletin of the School for Oriental and African Studies 78/3 (2015): 429-450.

Van Steenbergen, Jo, “'Mamlukisation' between social theory and social practice: An essay on reflexivity, state formation, and the late medieval sultanate of Cairo" (ASK Working Paper 22) (Bonn: Annemarie Schimmel Kolleg, 2015).

Van Steenbergen, Jo, Caliphate and Kingship in a Fifteenth-Century Literary History of Muslim Leadership and Pilgrimage (Bibliotheca Maqriziana. Opera Minora vol. 4) (Leiden \& Boston: Brill, 2016).

Van Steenbergen, Jo \& Maya Termonia, "State Formation, Military Entrepreneurship, and Waqfisation in the Sultanate of Cairo: the case of the court office of the ra's nawba, 1412-1468" (2021).

Van Steenbergen, Jo, Patrick Wing \& Kristof D'hulster, “The Mamlukization of the Mamluk Sultanate? State formation and the history of fifteenth century Egypt and Syria. Part I: old problems and new trends", History Compass 14/11 (2016): 549-559.

Van Steenbergen, Jo, Patrick Wing \& Kristof D'hulster, “The Mamlukization of the Mamluk Sultanate? State formation and the history of fifteenth century Egypt and Syria. Part II: comparative solutions and a new research agenda", History Compass 14/11 (2016): 560-569.

Walker, Bethany J., “The Phenomenon of the 'Disappearing' Villages of Late Medieval Jordan, as Reflected in Archaeological and Economic Sources", Bulletin d'études orientales 60 (2012): 161-176.

Watt, W. Montgomery, Islamic Political Thought (Edinburgh: Edinburgh University Press, 1968). 
Wing, Patrick, "Submission, Defiance, and the Rules of Politics on the Mamluk Sultanate's Anatolian Frontier", Journal of the Royal Asiatic Society 25/3 (2015): 377-388.

Woods, John, The Aqquyunlu. Clan, Confederation, Empire. Revised and Expanded Edition (Salt Lake City: The University of Utah Press, 1999).

Yapp, Malcolm E., The Making of the Modern Near East, 1792-1923 (Harlow: Pearson Education Ltd, 1987).

Yıldız, Sara Nur, "Razing Gevele and Fortifying Konya: the beginning of the Ottoman conquest of the Karamanid principality in South-Central Anatolia, 1468", Proceedings of the British Academy 156 (2009): 307-329.

Yosef, Koby, "Dawlat al-Atrāk or Dawlat al-Mamālīk? Ethnic Origin or Slave Origin as the Defining Characteristic of the Ruling Elite in the Mamluk Sultanate", Jerusalem Studies in Arabic and Islam 39 (2012): 387-410. 